\title{
THE STRUCTURE OF THE LITHOSPHERIC MANTLE OF THE SIBERAIN CRATON AND SEISMODYNAMICS OF DEFORMATION WAVES IN THE BAIKAL SEISMIC ZONE
}

\author{
A. A. Stepashko
}

\section{Kosygin Institute of Tectonics and Geophysics FEB RAS, Khabarovsk, Russia}

\begin{abstract}
The evolution and specific features of seismogynamics of the Baikal zones are reviewed in the context of interactions between deep deformation waves and the regional structure of the lithospheric mantle. The study is based on a model of the mantle structure with reference to chemical compositions of mantle peridotites from ophiolotic series located in the southwestern framing of the Siberian craton (Fig. 1). The chemical zonation of the lithospheric mantle at the regional scale is determined from results of analyses of the heterogeneity of compositions of peridotites (Fig. 2, Table 1) and variations of contents of whole rock major components, such as iron, magnesium and silica (Fig. 3). According to spatial variations of the compositions of peridotites, the mantle has the concentric zonal structure, and the content of $\mathrm{SiO}_{2}$ is regularly decreasing, while concentrations of $\mathrm{FeO}_{\Sigma}$ and $\mathrm{MgO}$ are increasing towards the centre of such structure (Fig. 4). This structure belongs to the mantle of the Siberian craton, which deep edge extends beyond the surface contour of the craton and underlies the northwestern segment of the Central Asian orogenic belt.
\end{abstract}

Results of the studies of peridotites of the Baikal region are consistent with modern concepts [Snyder, 2002; O'Reilly, Griffin, 2006; Chen et al., 2009] that suggest that large mantle lenses underlie the Archaean cratons (Fig. 5). The lenses are distinguished by high-density ultrabasic rocks and compose high-velocity roots of cratons which have remained isolated from technic processes. Edges of the mantle lenses may extend a few hundred kilometers beyond the limits of the cratons and underlie orogenic belts that frame the cratons, and this takes place in the south-western segment of the Siberian craton.

The revealed structure of the lithospheric mantle is consistent with independent results of seismic and magmatectonical studies of the region. The Angara geoblock is located above the central part of the mantle lense (Fig 6, A); it is one of four main tectonical units that compose the basement of the Siberian craton [Mironyuk, Zagruzina, 1983]. As evidenced by the zonal composition of the mantle lense, the centre of the lense is highly dense, and this explains the location of a seismic anomaly there (Fig. 6, B) which is determined to a depth of about 50-60 km [Pavlenkova G.A., Pavlenkova N.I., 2006]. The high-velocity root located in this segment of the craton is traced by seismic tomography [Koulakov, Bushenkova, 2010] to a depth of about $600 \mathrm{~km}$ (Fig. 7). The southward-stretching edge of the sub-cratonic mantle has played a major role in the evolution of the Central Asian orogenic belt. In the Paleozoic, the position and the configuration of the accretional margin of the Siberian paleocontinent were determined by the hidden boundary of the craton (Fig. 8, A). Along the craton's boundary, rifting zones of various ages are located, and intrusions are concentrated, which genesis was related to extension settings (Fig. 8, $B)$. The Cenozoic sedimentary basins are located above the hidden edge of the Siberian craton, which gives evidence of involvement of the deep lithospheric structure in the formation of the recent destruction zone. The basin of Lake Baikal is located along the mantle edge of the Siberian craton, and the basin's crescent shape accentuates the strike of the mantle edge.

In the region under study, the wave nature of seismicity is most evidently manifested by the cyclicity of the strongest earthquakes in the Baikal zone (Table 2). Three seismic cycles are distinguished as follows: (1) at the turn of the $20^{\text {th }}$ century (earthquakes in the period from 1885 to $1931, \mathrm{M}=6.6-8.2)$, (2) the middle of the $20^{\text {th }}$ century (earthquakes from 1950 to 1967, $M=6.8-8.1$ ), and (3) at the turn of the 21st century (earthquakes from 1991 to 2012, $M=6.3-7.3$ ). While moving in the mantle, the deformation front collapses with the craton's basement, partially releases its energy to the lithosphere and involves the fragmented edge of the crust overlying the craton's edge into deformation (Fig. 9, A). This interaction resulted in the formation of the Mongolia-Baikal and the Altai-Baikal seismic sutures whereat all the strong earthquake took place in seismic cycles (1) and (3), respectively (Fig. 9, B). The third, West Amur seismic suture framing the boundary of the Amur plate comprises locations of strong earthquakes that occurred in cycle (2) (Fig. 10). An important specific feature of the Baikal seismic zone is orthogonal migration of earthquakes within seismic sutures. In each of the sutures, epicenters of strong earthquakes $(M>6.0)$ migrated in the transverse direction, which established the orientation of maximum compression during interaction of deformation waves with the mantle structures (Fig. 9, and 10). The less strong seismic events (M<6.0) (Fig. 11) migrated along the seismic sutures. At the western flank of the zone, in the Altai-Baikal and Mongolia-Baikal sutures, latitudinal migration took place in the direction from west to east with account of the trajectory of the deformation wave. In the northern part of the West Amur suture, latitudinal migration was directed from east to west, and its direction was gradually changed to meridional in the southern part, which reflected the anticlockwise rotation of the Amur plate. This conclusion can 
explain a paradox of counter migration of seismicity in the Baikal zone, which is revealed by S.I. Sherman [Sherman, Zlogodukhova, 2011].

In each of the three seismic/deformation sutures, stresses are released via orthogonal multi-directional migration of earthquakes (Fig. 12), and the sutures are regularly combined to compose a complex structure of the stress field in the Baikal seismic zone. Their positions predetermine locations of the major riftogenic structures, primarily sedimentary basins from Tunka to Ubsunur (Fig. 9, B). The three seismic sutures join and overlap each other in the area of Lake Baikal and thus set up the maximum intensity of deformation in this area. Apparently, each of the deformation sutures corresponds to one of the three basins of Lake Baikal (Fig. 13, A). Their depths are correlated with widths of the sutures, which is explained by 'weakening' of the deformation wave in the successive cycles of its interaction with the deep structure of the lithosphere. Seismicity of the Baikal zone and its Cenozoic rifting reflect the character of the stress field generated by interaction between the deep deformation wave and the organization of the lithospheric mantle.

Key words: Siberian craton, sub-craton mantle, zonation of the mantle, structure of the lithosphere, Baikal seismic zone, deformation waves, migration of earthquakes, seismic cycles, Amur plate, Baikal rift.

Recommended by S.I. Sherman

Citation: Stepashko A.A. 2013. The structure of the lithospheric mantle of the Siberain craton and seismodynamics of deformation waves in the Baikal seismic zone. Geodynamics \& Tectonophysics 4 (4), 387-415. doi:10.5800/GT-2013-4-4-0108.

\title{
СТРУКТУРА ЛИТОСФЕРНОЙ МАНТИИ СИБИРСКОГО КРАТОНА И СЕЙСМОДИНАМИКА ДЕФОРМАЦИОННЫХ ВОЛН В БАЙКАЛЬСКОЙ СЕЙСМИЧЕСКОЙ ЗОНЕ
}

\section{А. А. Степашко}

\section{Институт тектоники и геофизики им. Ю.А. Косыгина ДВО РАН, Хабаровск, Россия}

\begin{abstract}
Аннотация: Образование и особенности сейсмодинамики Байкальской зоны рассматриваются в контексте взаимодействия глубинных деформационных волн с региональной структурой литосферной мантии. В основе работы модель мантийной структуры, для реконструкции которой использованы химические составы мантийных перидотитов из офиолитовых комплексов, расположенных в юго-западном обрамлении Сибирского кратона (рис. 1). Анализ гетерогенности состава перидотитов (рис. 2, табл. 1) и вариаций содержаний в них главных породообразующих компонентов: железа, магния и кремния (рис. 3) позволил определить химическую зональность литосферной мантии регионального масштаба. Пространственные вариации состава перидотитов отражают концентрически-зональную мантийную структуру, к центру которой систематически уменьшаются содержания $\mathrm{SiO}_{2}$ и возрастают концентрации $\mathrm{FeO}_{\Sigma}$ и $\mathrm{MgO}$ (рис. 4). Обнаруженная структура принадлежит мантии Сибирского кратона, глубинный край которого выходит за пределы его поверхностного контура, подстилая северо-западную часть Центрально-Азиатского орогенного пояса.

Результаты изучения перидотитов Байкальского региона согласуются с современными представлениями [Snyder, 2002; O’Reilly, Griffin, 2006; Chen et al., 2009], по которым под архейскими кратонами располагаются крупные мантийные линзы (рис. 5). Они отличаются повышенной плотностью ультраосновного вещества и образуют высокоскоростные корни кратонов, остававшиеся изолированными в тектонических процессах. Как и в юго-западной части Сибирского кратона, края мантийных линз могут выходить на сотни километров за пределы кратонов, подстилая орогенные пояса их обрамления.

Реконструкция структуры литосферной мантии согласуется с независимыми результатами сейсмических и тектономагматических исследований региона. Над центральной частью мантийной линзы расположен Ангарский геоблок (рис. 6, A), один из четырех главных тектонических элементов фундамента Сибирской платформы [Myronyuk, Zagruzina, 1983]. Зональность состава мантийной линзы определяет высокую плотность в ее центре, что объясняет положение здесь сейсмической аномалии (рис. 6, B), выделенной для глубины 50-60 км [Pavlenkova G.A., Pavlenkova N.I., 2006]. Расположенный в этой части кратона высокоскоростной корень прослеживается по данным сейсмотомографии [Koulakov, Bushenkova, 2010] до глубины 600 км (рис. 7). Выдвинутый на юг край подкратонной мантии играл важную роль в тектонической эволюции Центрально-Азиатского орогенного пояса. В палеозое скрытая граница кратона определяла положение и конфигурацию аккреционной окраины Сибирского палеоконтинента (рис. 8, A). Вдоль нее также располагаются разновозрастные зоны рифтогенеза, концентрируются интрузии, генезис которых связан с обстановками растяжения (рис. 8, B). Над скрытым мантийным краем Сибирского кратона расположены кайнозойские осадочные впадины, что говорит об участии глубинной структуры литосферы в образовании современной зоны деструкции. Впадина озера Байкал вытянута вдоль мантийного края Сибирского кратона, подчеркивая своей серповидной формой его простирание.
\end{abstract}


Волновая природа сейсмичности наиболее проявлена в цикличности самых сильных землетрясений Байкальской зоны (табл. 2). Выделяются три сейсмических цикла: 1 - рубеж XIX-XX вв. (землетрясения 1885-1931 гг., M=6.68.2), 2 - середина XX в. (толчки 1950-1967 гг., M=6.8-8.1), 3 - рубеж XX-XXI вв. (события 1991-2012 гг., M=6.37.3). Перемещаясь в мантии, деформационный фронт сталкивается с основанием кратона, отдает литосфере часть энергии и вовлекает в деформации раздробленный край коры, расположенный над краем кратона (рис. 9, $A$ ). Результатом этого взаимодействия стало образование Монголо-Байкальского и Алтае-Байкальского сейсмических швов, в которых концентрируются все сильные землетрясения первого и последнего сейсмических циклов, соответственно (рис. 9, B). Сильные землетрясения середины XX в. (2-й цикл) образуют третий (Западно-Амурский) сейсмический шов, обрамляющий границу Амурской плиты (рис. 10). Важной особенностью Байкальской сейсмической зоны является ортогональная миграция землетрясений в пределах сейсмических швов. В каждом из швов обнаружена поперечная миграция эпицентров сильных землетрясений с $\mathrm{M}>6.0$, которая фиксирует ориентацию максимального сжатия при взаимодействии деформационной волны с мантийными структурами (рис. 9, 10). Миграция более слабых землетрясений с магнитудами $\mathrm{M}<6.0$ (рис. 11) происходит вдоль сейсмических швов. На западном фланге зоны в Алтае-Байкальском и Монголо-Байкальском швах продольная миграция, с учетом траектории деформационной волны, направлена с запада на восток. В Западно-Амурском шве продольная миграция направлена с востока на запад в северной части и постепенно меняет направление на меридиональное на юге, отражая вращение Амурской плиты против часовой стрелки. Это следствие объясняет парадокс встречной миграции сейсмичности в Байкальской зоне, обнаруженной С.И. Шерманом [Sherman, Zlogodukhova, 2011].

Закономерное сочетание трех сейсмических/деформационных швов, в каждом из которых стресс реализуется в виде разнонаправленной ортогональной миграции землетрясений (рис. 12), формирует сложную структуру поля напряжений в Байкальской сейсмической зоне. Позиция швов предопределяет расположение основных рифтогенных структур, прежде всего осадочных впадин, от Тункинской до Убсунурской (рис. 9, B). В районе озера Байкал все сейсмические швы смыкаются и накладываются друг на друга, что определяет максимальную интенсивность деформаций. Каждому из деформационных швов зоны, видимо, отвечает одна из трех котловин озера (рис. 13, А). Их глубина коррелирует с шириной швов, что объясняется «ослаблением» деформационной волны при последовательных циклах ее взаимодействия с глубинной структурой литосферы. Сейсмичность Байкальской зоны и ее кайнозойский рифтогенез с разных сторон отражают характер поля напряжений, генезис которого определен взаимодействием глубинной деформационной волны с организацией литосферной мантии.

Ключевые слова: Сибирский кратон, подкратонная мантия, зональность мантии, структура литосферы, Байкальская сейсмическая зона, деформационные волны, миграция землетрясений, сейсмические циклы, Амурская плита, Байкальский рифт.

\section{1. ВВЕДЕНИЕ}

Геодинамическая природа зон внутриплитной сейсмичности относится к числу наиболее важных, но до сих пор крайне дискуссионных и малопонятных проблем современной сейсмологии [Stone, 2008; Zoback, 2010]. Это в полной мере касается и Байкальской сейсмической зоны, несомненно, самой известной и наиболее опасной из областей внутриплитной сейсмичности России [Sherman, 2009; Sherman, Zlogodukhova, 2011]. Ее генезис и особенности в прошедшие десятилетия тщательно изучались и многократно обсуждались с разных позиций [Zonenshain, Savostin, 1979; Zorin, Turutanov, 2005; Logachev, 2003; Rundquist et al., 1999; Sherman, 2009]. Впечатляющий объем накопленной эмпирической информации и идейное богатство проведенных исследований не должны заслонять тот факт, что сейсмотектоника до сих пор не располагает глубокой аргументацией тех геодинамических факторов, действие которых вызывает сильные землетрясения региона.

Фундаментальная идея, без которой невозможно, по нашему мнению, понять природу внутриплитной сейсмичности, сформулирована в гипотезе деформационных волн [Bykov, 2005; Vikulin et al., 2000; Ulomov,
1993; Sherman, 2009, 2013]. Самые сильные из таких волн, по-видимому, образуются в районах аномальной концентрации сжатия на границах плит и периодически распространяются или в самой литосферной мантии, или вдоль кровли астеносферы [Malamud, Nikolaevsky, 1983, 1985; Stepashko, 2011b]. Для Байкальской сейсмической зоны ближайшим районом аномального сжатия является Памиро-Гиндукушский узел Гималайской области коллизии Евроазиатской и ИндоАвстралийской плит [Zonenshain, Savostin, 1979; Ivanova, Trifonov, 2005; Malamud, Nikolaevsky, 1985; Molnar, Tapponnier, 1975]. По нашему мнению, здесь образуется деформационная волна, которая вносит главный вклад в сейсмичность Байкальской зоны. Уходя затем на восток, эта же волна деформаций, по всей видимости, вызывает сильные землетрясения Приамурья, Приморья и Сахалина [Stepashko, 2010, 2011a].

Деформационные волны максимальной интенсивности приводят к региональной активизации литосферы, причем размеры областей, вовлеченных в процесс, могут составлять десятки и сотни тысяч квадратных километров [Stepashko, 2011b; Sherman, 2009, 2013]. Принимая во внимание глубину распространения деформационных волн и учитывая масштаб процессов, следует предполагать, что особенности строения лито- 
сферной мантии играют существенную роль в генезисе зон внутриплитной сейсмичности. Это предположение доказало свою эффективность при изучении генезиса сильных внутриплитных землетрясений Дальнего Востока России и Северного Китая [Stepashko, 2010, $2011 a, 2011 b]$ и ниже использовано для понимания природы Байкальской сейсмической зоны.

Особый интерес, с нашей точки зрения, вызывают структурные особенности, отражающие вариации состава литосферной мантии. Еще недавно существование таких структур с тектонических позиций казалось маловероятным. Общепринятым считалось то, что вещество верхней мантии хорошо перемешано к настоящему времени в результате многократных планетарных циклов конвекции и субдукции. Однозначность этого постулата была поставлена под сомнение еще в семидесятые годы при обнаружении высокоскоростных мантийных зон, подстилающих архейские кратоны [Jordan, 1978]. Сейсмотомография подтвердила широкое развитие таких высокоскоростных корней и показала, что они вертикально погружаются под кратонами до глубины 300-400 км, а порой и глубже [Gossler, Kind, 1996; Polet, Anderson, 1995]. Современное изучение изотопного и геохимического состава глубинных ксенолитов подтвердило и аномальный возраст мантии архейских кратонов, который достигает, как правило, 2-3 млрд лет, и ее отличие по составу от мантии окружающих орогенных поясов протерозоя и фанерозоя [Griffin et al., 2009; Lee et al., 2011; Luguet et al., 2009; O'Reilly, Griffin, 2006; Pearson, 1999; Sny$d e r, 2002]$. Подкратонная мантия, играющая важнейшую роль в строении континентальной литосферы, является, таким образом, древней и сохранила свою вещественную изолированность в тектонической эволюции.

В настоящее время формируется принципиально новое представление о составе и структуре континентальной литосферной мантии, ключевые идеи которого кратко рассмотрены ниже применительно к Сибирскому кратону. Хотя основную информацию о мантии традиционно получают с помощью геофизических, прежде всего сейсмических, методов, работы прошедшего десятилетия показали также важность петрогеохимического исследования мантийного вещества. Использованный в работе подход основан на изучении зональности состава перидотитов мантии, которая, по нашему опыту, дает уникальную информацию о структуре литосферной мантии [Stepashko, 1998, 2010]. Анализ зональности перидотитовых протрузий из офиолитов Алтае-Саянской области позволяет установить особенности мантийного строения юго-западного края Сибирского кратона, которые хорошо согласуются с результатами глубинных сейсмических исследований [Koulakov, Bushenkova, 2010; Pavlenkova G.A., Pavlenkova N.I., 2006]. Высокое соответствие двух независимых «образов» литосферной мантии - сейсмического и петрогеохимического - принципиально и позволяет предполагать правомерность реконструкции мантийной структуры региона. Мантия Сибирского кратона протягивается далеко на юг под структуры Центрально-Азиатского орогенного пояса, образуя глубинное основание Байкальской сейсмической зоны. Модель образования зоны, основные черты которой рассматриваются ниже, предполагает, что пространственно-временное распределение сильных землетрясений является отражением у поверхности литосферного взаимодействия деформационных волн с погруженным мантийным краем Сибирского кратона.

\section{2. ВАРИАЦИИ СОСТАВА ПЕРИДОТИТОВ И ЗОНАЛЬНОСТЬ ЛИТОСФЕРНОЙ МАНТИИ АЛТАЕ-САЯНСКОГО РЕГИОНА}

Для расшифровки структуры мантии Байкальской сейсмической зоны особый интерес представляют многочисленные тела (блоки) перидотитов из рифейраннекембрийских офиолитов, которые очень широко распространены в Алтае-Саянской аккреционной области (рис. 1). Такие ультрабазиты являются, как общепризнано, фрагментами мантийного вещества, перемещенными на поверхность в виде тектонических протрузий. Они были подняты приблизительно с глубины 40-60 км и характеризуют состав литосферной мантии.

Вопрос о зональности состава мантийных перидотитов региона ранее поднимался [Velinsky, Vartanova, 1980], но остался без удовлетворительного решения, прежде всего потому, что изучались породы лишь Тувы и Сангилена, а такой масштаб сравнения, как будет ясно в дальнейшем, явно недостаточен для обнаружения региональной зональности состава перидотитов.

В нашей работе сравнивался химический состав перидотитов из всех главных районов распространения офиолитов (рис. 1). Основные данные взяты из сводной работы Б.Н. Лапина [Lapin, 1997] и дополнены химическими анализами ультрабазитов Енисейского кряжа [Vernikovsky et al., 1994] и Прихубсугульского района Монголии [Lesnov, 1986]. При изучении региональной гетерогенности перидотитов и зональности состава мантии прежде всего интересны содержания главных компонентов перидотитов: кремния, железа и магния [Stepashko, 1998]. В сумме они составляют порядка 95 \% веса породы и, что важно, наиболее устойчивы ко вторичным преобразованиям. Содержания двух других породообразующих компонентов перидотитов - алюминия и кальция - существенно меньше и, как правило, сильно коррелируют с магнием, не неся дополнительной информации о структуре вариаций состава. Предварительно для устранения влияния степени серпентинизации все химические анализы по принятой методике пересчитывались на 100 \% суммы петрогенных компонентов, железо приводилось к общей форме. 


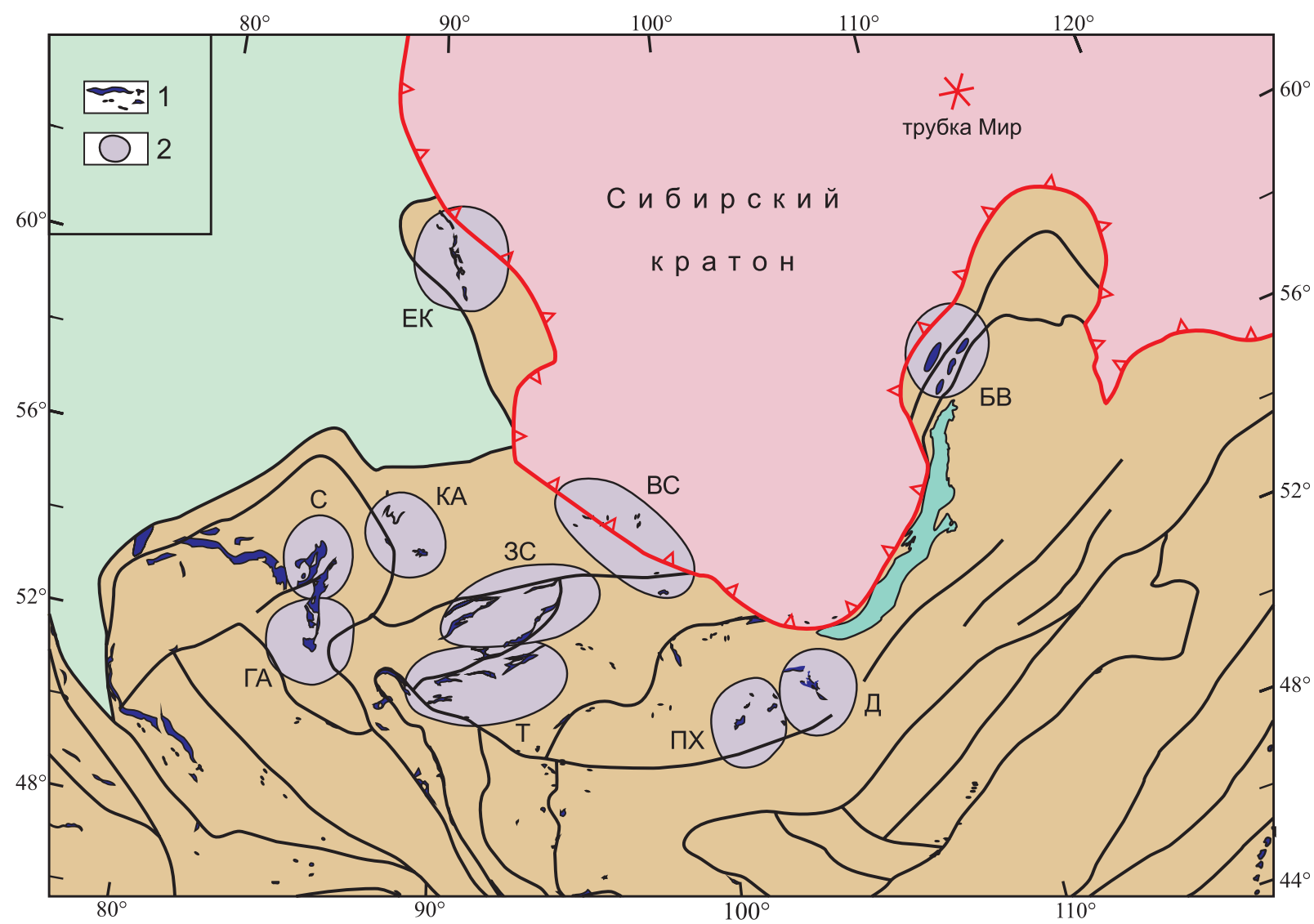

Рис. 1. Положение мантийных перидотитов у юго-западной окраины Сибирского кратона.

1 - офиолитовые комплексы с ультрабазитами в структуре Центрально-Азиатского орогенного пояса; 2 - основные районы, для которых анализировался состав мантийных перидотитов: ЕК - Енисейский кряж [Vernikovsky et al., 1994], С - Салаир, ГА - Горный Алтай, КА Кузнецкий Алатау, ЗС - Западный Саян, ВС - Восточный Саян, Т - Тува, БВ - Байкало-Витимский, Д - Джидинский [Lapin, 1997], ПХ Прихубсугульский [Lesnov, 1986]. Звездочкой отмечена позиция кимберлитовой трубки Мир. Красная линия с бергштрихами показывает границу Сибирского кратона, окрашенного розовым цветом. Коричневым цветом обозначена северо-западная часть ЦентральноАзиатского орогенного пояса. В его пределах показана позиция основных тектонических нарушений.

Fig. 1. Positions of mantle peridotites at the south-western margin of the Siberian craton.

1 - ophiolite series with ultrabasites in the structure of the Central Asian orogenic belt; 2 - main areas with analysed compositions of the mantle peridotites: EK - Yenisei ridge [Vernikovsky et al., 1994], C - Salair, ГA - Gorny Altai, KA - Kuznetsky Altai, 3C - West Sayan, BC - East Sayan, Т - Tuva, БВ - Baikal-Vitim, Д - Dzhida [Lapin, 1997], ПХ - Prekhubsugul [Lesnov, 1986]. The star shows the Mir kimberlite pipe. The red line with hachures shows the boundary of the Siberian craton (see the pink area). The north-western part of the Central Asian orogenic belt is shown in brown. Major tectonic faults are shown by black lines.

Закономерности состава ультрабазитов региона. Особенностью перидотитов Алтае-Саянской области являются сильные вариации содержаний железа, отражающие гетерогенность их состава. Породы большинства изученных районов на диаграммах $\mathrm{FeO} / \mathrm{MgO}$ распадаются на группы, примеры такой неоднородности приведены для перидотитов Салаира,Тувы и БайкалоВитимского района (рис. 2, $A-C$ ). По содержаниям железа средние составы однородных групп, определенные для всех поясов (табл. 1), распадаются на две самостоятельные совокупности (рис. 2, Д). Разрыв распределения между ними предполагает закономерный характер обнаруженной неоднородности. Образование ультрабазитов разного уровня железистости при этом явно не связано со степенью деплетированности ман- тии, так как две совокупности мало различаются по положению на диаграмме $\mathrm{Al}_{2} \mathrm{O}_{3} / \mathrm{MgO}$ (рис. 3, A). Все составы на ней образуют общий тренд истощения примитивной мантии (ПМ), в низкомагнезиальную часть которого попадают также средние составы мантийных ксенолитов из кайнозойских вулканов Хамар-Дабана и Джиды [Ashchepkov, 1991; Kiselev et al., 1979].

Наиболее высокие содержания магния характерны, как обнаружено, для мантии древних кратонов [Griffin et al., 2009; Luguet et al., 2009; Pearson, Wittig, 2008]. Если подразделить литосферную мантию на типы по возрасту коры [Griffin et al., 1999]: Archon (>2.5 млрд лет), Proton (2.5-1.0 млрд лет), Tecton (<1.0 млрд лет), то обнаруживается, что в соответствующих перидотитах содержания магния уменьшаются с омоложением 

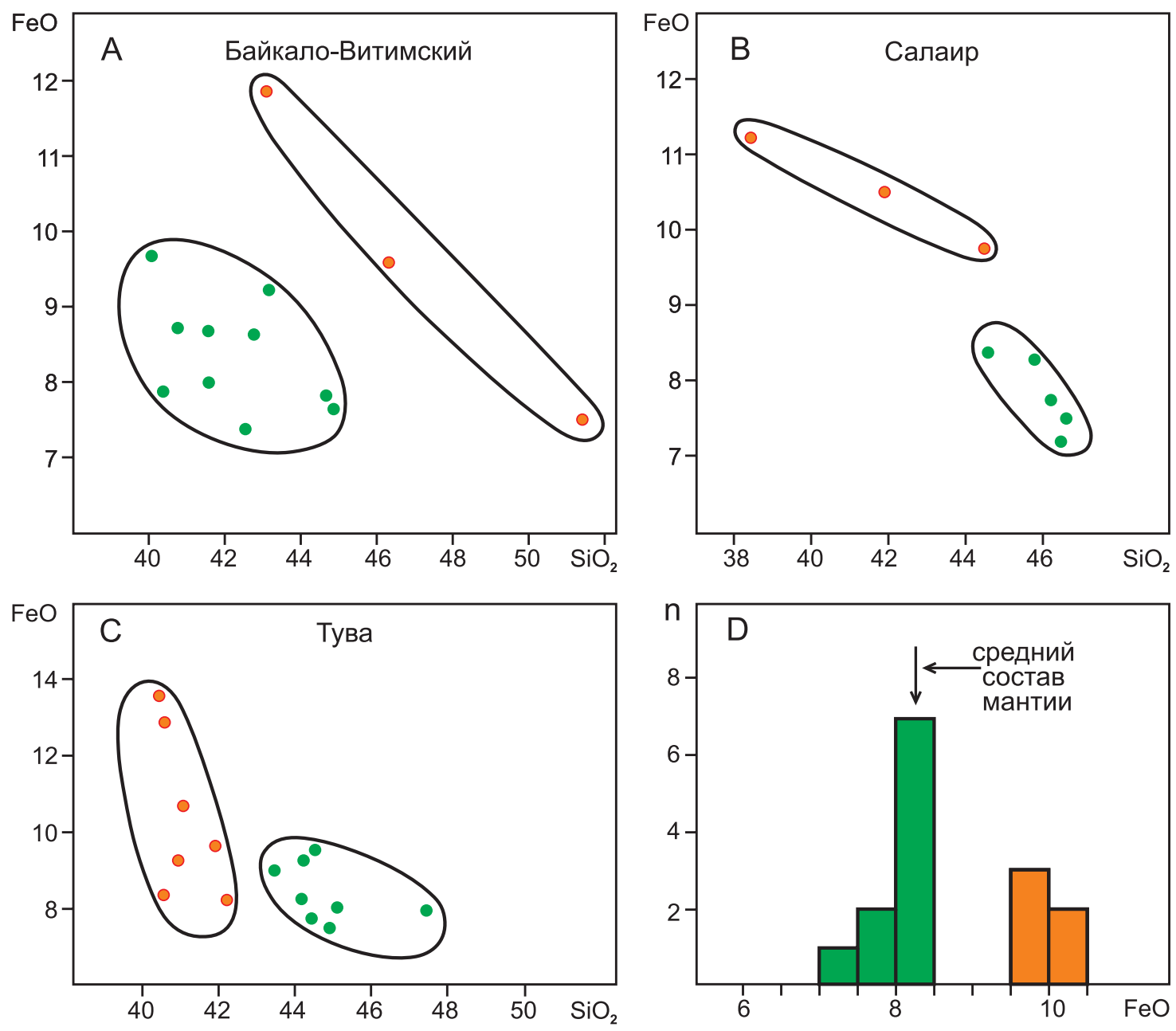

Рис. 2. Гетерогенность мантийных перидотитов из офиолитов Алтае-Саянского региона.

$A, B, C$ - распределения ультрабазитов в трех районах. Цветом выделены однородные группы, для которых рассчитывался средний состав; $D$ - гистограмма содержаний суммарного железа для средних составов групп Алтае-Саянского региона.

Fig. 2. Heterogeneity of mantle peridotites from ophiolites of the Altai- Sayan region.

$A, B, C$ - distribution of ultrabasites in the three areas. Highlighted are homogeneous groups with calculated average compositions; $D$ - histogram showing bulk iron contents for average compositions of groups in the Altai- Sayan region.

возраста кратонов (рис. 3, А). Перидотиты Алтае-Саянской области по степени истощения относятся, в этом контексте, к самой магнезиальной мантии наиболее древних архейских кратонов.

Существование пород с разным уровнем железистости (см. рис. 2, Д) является отражением закономерной структуры вариаций состава. На диаграммах $\mathrm{FeO} / \mathrm{MgO}, \mathrm{FeO} / \mathrm{SiO}_{2}$ перидотиты образуют серии (полосы), расположенные параллельно (рис. 3, B, C). Каждой из двух совокупностей, выделенных выше по содержаниям железа, отвечает своя серия. Видимо, к отдельной серии следует отнести перидотиты Кузнецкого Алатау, которые отличаются крайне низкими содержаниями железа (рис. 3, B, C). Для распределений такого типа (их удобно обозначать как «спектральные структуры вариаций» [Stepashko, 1998]) характерны закономерные связи содержаний главных компонен- тов: магния, кремния и железа. В сериях перидотитов Алтае-Саянского региона хорошо выражена положительная корреляция $\mathrm{FeO}$ и $\mathrm{MgO}$, рост которых компенсируется уменьшением содержаний $\mathrm{SiO}_{2}$. Обнаруженная спектральная структура объединяет перидотиты огромной области и является ключом к пониманию характера зональности литосферной мантии.

Особый интерес в этом отношении представляют породы главной серии, в которых содержания $\mathrm{FeO}$ отвечают диапазону 7.7-8.5 \% (табл. 1). В поля этой серии попадают эталонные составы литосферной мантии: архона, протона и тектона. Такой уровень железистости является характерным в целом для Земли, как для перидотитов из офиолитов разных регионов, так и для мантийных ксенолитов из кимберлитов и базальтов.

Сравнительный анализ перидотитов главной серии 
Т а б л и ц а 1. Составы однородных групп мантийных ультрабазитов Алтае-Саянской области

$\mathrm{T}$ a b l e 1. Compositions of homogeneous groups of mantle ultrabasites of the Altai-Sayan region

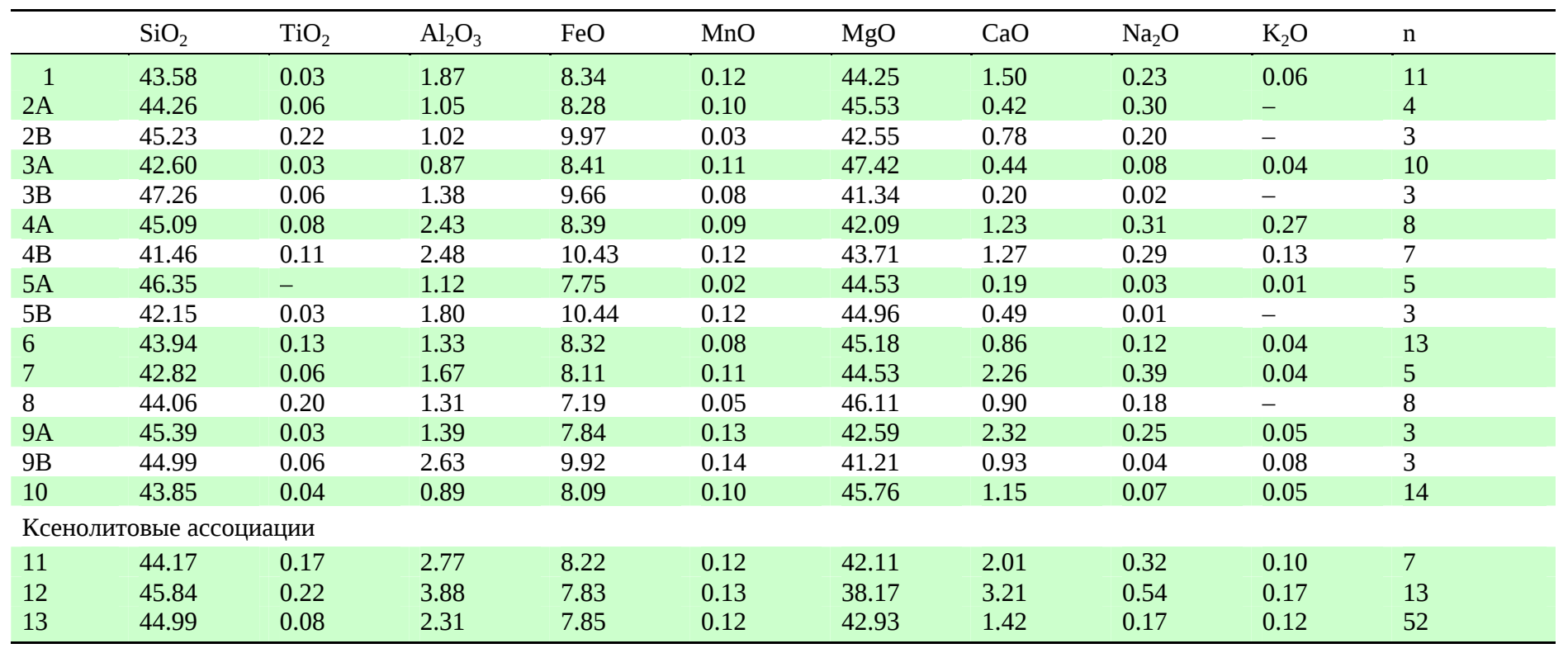

П р и м е ч а н и е. Средние составы мантийных перидотитов поясов: 1 - Восточного Саяна, 2 - Джидинского района, 3 - БайкалоВитимской области, 4 - Тувы, 5 - Салаира, 6 - Западного Саяна, 7 - Горного Алтая, 8 - Кузнецкого Алатау, 9 - Енисейского кряжа, 10 Прихубсугульского пояса. Для поясов под № 2, 3, 4, 5, 9 (левая колонка) приведены средние составы однородных (А, В) групп перидотитов. Зеленым цветом выделены составы нормальной железистости. Ксенолитовые ассоциации: 11 - Хамар-Дабана, 12 - Джидинского района, 13 - Трубки Мир. При расчетах использованы анализы по Б.Н. Лапину [Lapin, 1997], В.А. Верниковскому и др. [Vernikovsky et al., 1994], Ф.П. Леснову [Lesnov, 1986], И.В. Ащепкову и А.И. Киселеву и др. [Ashchepkov, 1991; Kiselev et al., 1979], Б.М. Владимирову и др. [Vladimirov et al., 1976].

$\mathrm{N}$ o t e. Average compositions of mantle peridotites in belts: 1 - East Sayan, 2 - Dzhida, 3 - Baikal-Vitim, 4 - Tuva, 5 - Salair , 6 - West Sayan, 7 - Altai, 8 - Kuznetsk Alatau, 9 - Yenisei ridge, 10 - Prekhubsugul belt. Average compositions of homogeneous (A, B) groups of peridotites are shown for the belts under numbers 2, 3, 4, 5, and 9 in the left column. Green - normal iron contents. Xenolith associations: 11 - Khamar-Daban, 12 - Dzhida, 13 - Mir kimberlitic pipe. Calculations are based on analyses according to B.N. Lapin [Lapin, 1997], V.A. Vernikovsky et al. [Vernikovsky et al., 1994], F.P. Lesnov [Lesnov, 1986], I.V. Ashchepkov and A.I. Kiselev et al. [Ashchepkov, 1991; Kiselev et al., 1979], and B.M. Vladimirov et al. [Vladimirov et al., 1976].

обнаруживает зональность состава мантии Алтае-Саянского региона, наиболее определенно в вариациях содержаний кремния (рис. 4). Менее отчетливо зональность выражена по магнию, на содержания которого гораздо сильнее влияет степень истощения, видимо, отличающаяся в разных районах. Единственным исключением в рисунке зональности являются перидотиты Горного Алтая, которые показывают самые низкие содержания $\mathrm{SiO}_{2}$. Среди изученных пород они занимают самое юго-западное положение и, возможно, являются фрагментами мантии уже из другой области. Перидотиты всех остальных девяти районов АлтаеСаянского региона намечают закономерную концентрическую поверхность вариаций, к центру которой содержания кремния систематически уменьшаются от 46 до 43 \%. Несомненно, изолинии компонента обрамляют выступающий на юг край Сибирского кратона и центр вариационной поверхности оказывается расположен далеко в контуре кратона. Это предполагает, что перидотиты Алтае-Саянской области являются фрагментами литосферной мантии Сибирского кратона. Подтверждением являются ксенолиты кимберлито- вой трубки «Мир», которые по содержаниям всех компонентов относятся к той же вариационной структуре (см. рис. 3). Содержания кремния в этих ксенолитах так же хорошо согласуются с концентрическим рисунком зональности мантии (рис. 4). В соответствии с корреляционными связями (см. рис. $3, B, C$ ) уменьшение содержаний кремния к центру поверхности вариаций сопровождается ростом в перидотитах содержаний магния и железа. Мантия под краем Сибирского кратона в центре концентрической поверхности должна отличаться самой высокой железистостью и магнезиальностью, а следовательно плотностью.

\section{3. СОВРЕМЕННЫЕ ПРЕДСТАВЛЕНИЯ О МАНТИИ КРАТОНОВ}

В последние 10-15 лет представления о структуре верхней мантии испытывают кардинальную трансформацию, и те новые идеи, которые сейчас активно развиваются, позволяют понять природу вариаций состава перидотитов Алтае-Саянской области.

Модель подкратонной мантии. Развитие геологии на 

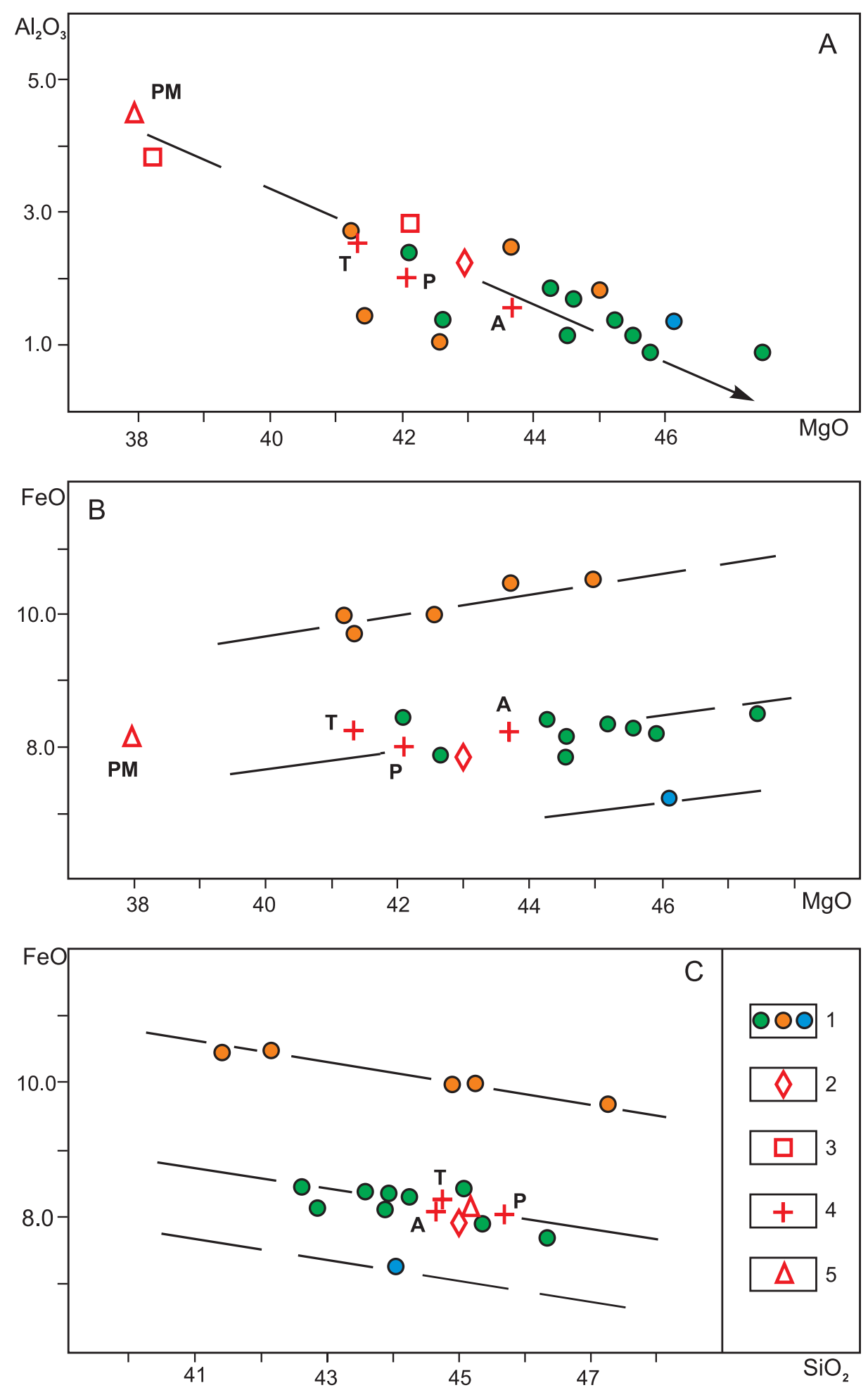

Рис. 3. Структура вариаций состава мантийных перидотитов Алтае-Саянского региона.

$A$ - тренд истощения мантии на диаграмме $\mathrm{Al}_{2} \mathrm{O}_{3} / \mathrm{MgO} ; \mathrm{B}, \mathrm{C}$ - спектральное распределение составов на диаграммах $\mathrm{FeO} / \mathrm{MgO}$ и $\mathrm{FeO} / \mathrm{SiO}$. Средние составы: 1 - однородных групп перидотитов по районам (табл. 1); 2 - ксенолитов кимберлитовой трубки Мир [Vladimirov et al., 1976]; 3 - мантийных ксенолитов из кайнозойских базальтов Джиды и Хамар-Дабана [Ashchepkov, 1991; Kiselev et al., 1979]; 4 - континентальной мантии, возрастные типы: А - архон, Р - протон, Т - тектон [Griffin et al., 1999]; 5 - примитивной мантии [McDonough, Sun, 1995].

Fig. 3. The pattern of variations in compositions of mantle peridotites in the Altai-Sayan region.

A - depleted mantle trend in $\mathrm{Al}_{2} \mathrm{O}_{3} / \mathrm{MgO}$ diagram; $\mathrm{B}, \mathrm{C}$ - spectral distribution of compositions in $\mathrm{FeO} / \mathrm{MgO}$ and $\mathrm{FeO} / \mathrm{SiO}{ }_{2}$ diagrams. Average compositions: 1 - homogeneous groups of peridotites by regions (Table 1); 2 - xenoliths of the Mir kimberlite pipe [Vladimirov et al., 1976]; 3 mantle xenoliths from the Cenozoic basalts of Dzhida and Khamar-Daban [Ashchepkov, 1991; Kiselev et al., 1979]; 4 - continental mantle by age types: A - Archon, P - Proton, T - Tecton [Griffin et al., 1999]; 5 - primitive mantle [McDonough, Sun, 1995]. 


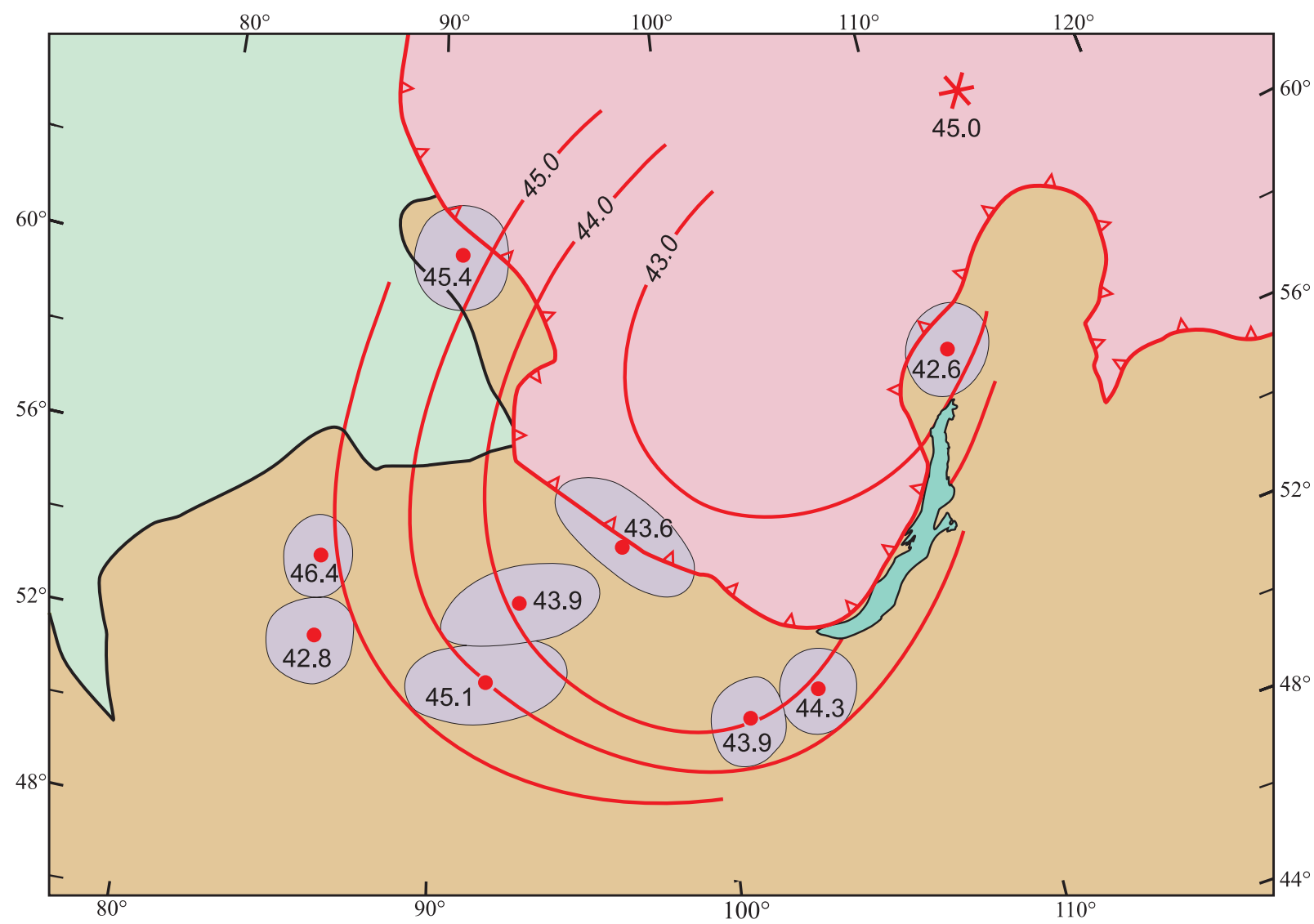

Рис. 4. Концентрически-зональный характер вариаций кремния в мантийных перидотитах юго-западного обрамления Сибирского кратона.

Цифры в овалах - средние содержания $\mathrm{SiO}_{2}$ в перидотитах нормальной железистости. Звездочка - кимберлитовая трубка Мир и содержания кремния в ее мантийных ксенолитах. Граница Сибирского кратона показана красной линией с бергштрихами. ЦентральноАзиатский орогенный пояс и Сибирский кратон окрашены коричневым и розовым цветом, соответственно.

Fig. 4. Concentrically zonal variations of silica in mantle peridotites of the south-western framing of the Siberian craton.

Numbers in the ovals show average contents of $\mathrm{SiO}_{2}$ in peridotites with normal iron contents. The star shows the Mir kimberlite pipe. The red line with hachures shows the boundary of the Siberian craton (shown in pink). The Central Asian orogenic belt is shown in brown.

рубеже XX-XXI вв. подтвердило справедливость идей о структуре мантии, высказанных в работе [Jordan, 1978]. Одним из главных достижений сейсмотомографии конца века стало доказательство существования глубинных высокоскоростных корней архейских кратонов, которые пронизывают весь разрез верхней мантии до глубины 400-500 км [Gossler, Kind, 1996; Gudmundsson, Sambridge, 1998; Polet, Anderson, 1995].

Детальное изучение мантийных ксенолитов из кимберлитов с помощью самых современных изотопногеохронологических (Rb-Sr, Sm-Nd, Re-Os) методов показало древний, часто архейский, возраст подкратонной мантии [Ferrini, Sassano, 1999; Lee et al., 2011; Menzies et al., 1998; Pearson, 1999; Pearson et al., 1999; Rudnick, Walker, 2009; Xu et al., 2008]. Судя по сводным данным о Re-Os возрасте ксенолитов из кимберлитов кратонных областей Южной Африки, Канады, Гренландии, Танзании, США и Сибири, мантия, как правило, древнее 1 млрд лет, причем выраженный мак- симум распределения возрастных оценок приходится на 2.5-3.0 млрд лет [Luguet et al., 2009]. Исследования ксенолитов из кимберлитовых трубок подтвердили систематическое отличие кратонной мантии по химическому составу [Griffin et al., 2009; Pearson, Wittig, 2008; Wittig et al., 2008]. Высокая скорость сейсмических волн в корнях кратонов вызвана, как предполагается, высокими содержаниями $\mathrm{MgO}$, которые в мантии континентов систематически возрастают в ряду «тектон» - «протон» - «архон».

Исследования петрохимии и геохимии мантийных ультрабазитов, а также их минералов, проведенные в последние два десятилетия, обнаружили химическую расслоенность литосферной мантии [Stepashko, 1998; Ishikawa et al., 2004; O’Reilly, Griffin, 2006]. Проявления химической стратификации были установлены по разным признакам при изучении ксенолитов архейских областей: Канады (Slave Craton) [Griffin et al., 1999], Южной Австралии [Gaul et al., 2000], Фенно- 


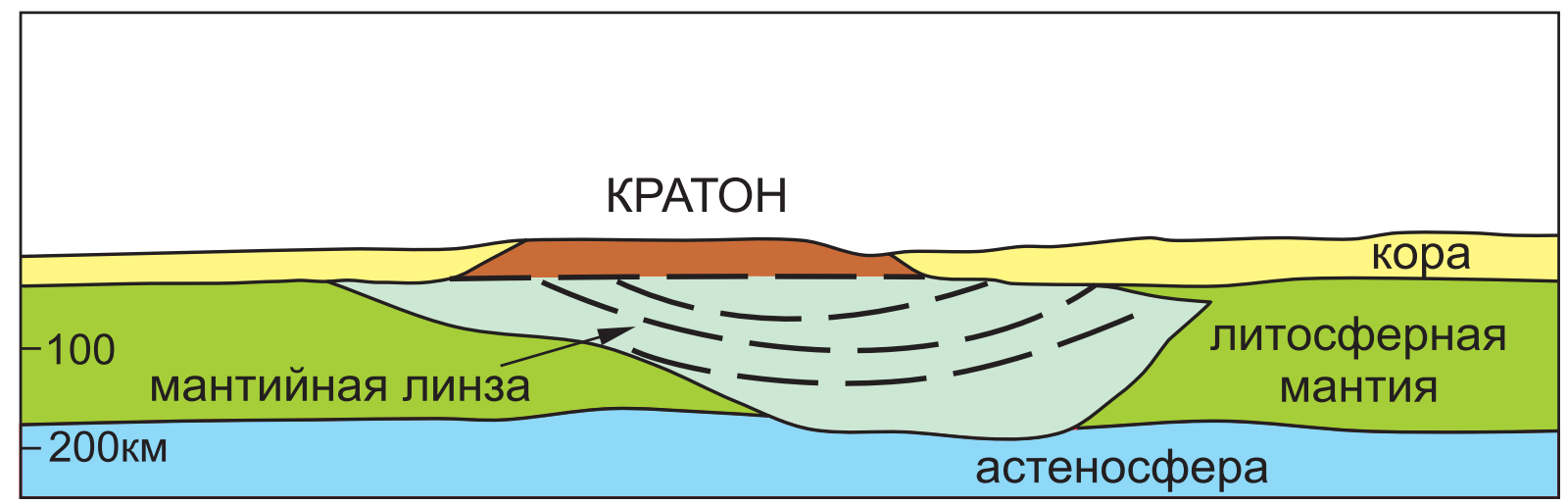

Рис. 5. Принципиальная схема строения литосферной линзы на основе модели подкратонной мантии кратона Slave [Snyder, 2002], с упрощениями и дополнениями.

Астеносфера показана голубым, литосферная мантия - зеленым, кора - желтым цветом. Коровая часть литосферной структуры кратона окрашена коричневым, мантийная часть - зеленовато-синим цветом. Пунктиром обозначены условные границы расслоенности мантийной линзы по химическому составу.

Fig. 5. A schematic diagram showing the structure of the lithospheric lense according to the model of the sub-cratonic mantle of the Slave craton [Snyder, 2002] (simplified and added).

Colour codes: blue - the asthenosphere, green - the lithospheric mantle, yellow - the crust, brown - the crustal part of the lithospheric structure of the craton, greenish-blue - the mantle part. Dashed lines show conventional boundaries of layers of the mantle lense which differ in chemical composition.

скандии [Peltonen, Brugmann, 2006], Венесуэлы [Schulze et al., 2006], ЮАР (кратоны Каапвааль и Калахари [Kuskov et al., 2006; Wittlinger, Farra, 2007], Западной Гренландии [Sand et al., 2009] и Индии [Patel et al., 2010]. Гипотеза «тонкой» верхнемантийной стратификации нашла независимое подтверждение в результатах глубинных сейсмических исследований, проведенных в последние годы [Wittlinger, Farra, 2007; Yuan, Romanowicz, 2010; Pavlenkova, 2011].

Принципиальная модель строения подкратонной мантии предложена Д.В. Снайдером на примере североамериканского кратона Slave (рис. 5) и опирается на результаты изучения архейских областей на базе глубинного сейсмического профилирования и сравнительного анализа геохимии ксенолитов [Snyder, 2002; O’Reilly, Griffin, 2006; Chen et al., 2009]. Две особенности данной модели имеют для нас важное значение. Во-первых, подкратонная мантия имеет, по всей видимости, линзовидную форму. Во-вторых, как показал специальный анализ глубинных границ кратона, край мантийной линзы может протягиваться на сотни километров под более молодыми аккреционно-складчатыми поясами обрамления [Snyder, 2002; O’Reilly, Griffin, 2006]. Горизонтальные размеры верхней коровой части кратона оказываются в этом случае значительно меньше по сравнению с его глубинным мантийным основанием.

Литосферная мантия Сибирского кратона. Близкая картина глубинной организации постепенно проявляется для Сибирского кратона. В его литосферной мантии по результатам сверхглубинного сейсмического зондирования с помощью мирных атомных взрывов выделено несколько скоростных аномалий, которые можно рассматривать как сложный корень кратона [Pavlenkova G.A., Pavlenkova N.I., 2006]. Сейсмотомографическое моделирование показывает [Koulakov, Bushenkova, 2010], что высокоскоростная зона в югозападной части кратона опускается до глубины 500 600 км. Мантия Сибирского кратона является древней. Для алмазоносных ксенолитов трубки Удачная получено значение $2.94 \pm 0.38$ млрд лет [Pearson, 1999]. Образование сульфидных включений из кристалла якутского алмаза произошло в интервале 3.1-3.5 млрд лет назад [Pearson et al., 1999]. Изучение вариаций состава мантийных ультрабазитов Сибирского кратона показало химическую расслоенность его литосферной мантии [Stepashko, 2001]. Идея стратификации подкратонной мантии получила развитие при детальном изучении геохимии и термодинамики мантийных ксенолитов из кимберлитовых трубок Якутской провинции [Ashchepkov et al., 2010]. Тонкую расслоенность верхней мантии по скоростным характеристикам убедительно демонстрируют результаты региональных сейсмических исследований Сибирской платформы [Egorkin, 2004; Pavlenkova, 2011].

В контексте современных представлений о подкратонной мантии закономерности вариаций состава перидотитов Алтае-Саянской области имеют очевидную интерпретацию. Серии пород с разным уровнем железистости (см. рис. $3, B, C$ ) отражают химическую стратификацию, и перидотиты из офиолитов региона первоначально принадлежали двум, возможно трем слоям 


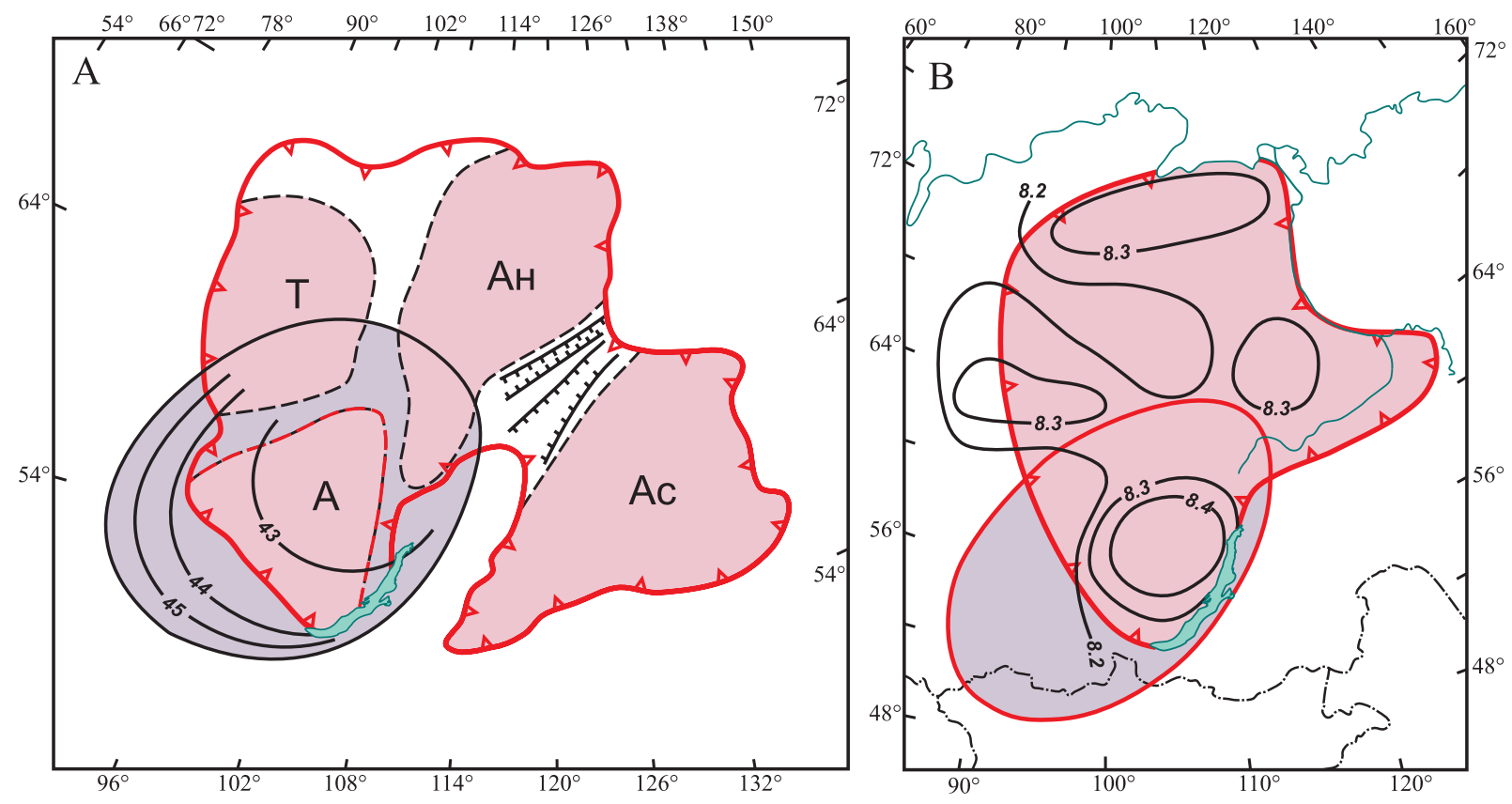

Рис. 6. Позиция мантийной линзы и особенности строения литосферы Сибирского кратона.

A - мегаблоки фундамента Сибирского кратона: А - Ангарский, Т - Тунгусский, Ан - Анабарский, Ас - Алдано-Становой [Mironyuk, Zagruzina, 1983]; B - положение высокоскоростных сейсмических аномалий в литосферной мантии на глубине 60 км [Pavlenkova G.A., Pavlenkova N.I., 2006]. Фиолетовым цветом показана предполагаемая мантийная линза на югозападной окраине Сибирского кратона.

Fig. 6. The position of the mantle lense and specific features of the lithospheric structure of the Siberian craton.

A - megablocks of the basement of the Siberian craton: A - Angara, T - Tunguska, An - Anabar, Ac - Aldan-Stanovoy [Mironyuk, Zagruzina, 1983]; $B$ - positions of high-velocity seismic anomalies in the lithospheric mantle at the depth of $60 \mathrm{~km}$ [Pavlenkova G.A., Pavlenkova N.I., 2006]. The supposed mantle lense at the south-western margin of the Siberian craton is shown in purple.

литосферной мантии. Результаты экспериментов по высокобарическому плавлению мантийных лерцолитов показывают, что железо является чувствительным индикатором давления [Herzberg, 2004; Ionov, Hofmann, 2007]. Перидотиты более железистой группы Алтае-Саянского региона, исходя из этих данных, являются фрагментами верхнего слоя мантии. Концентрическое изменение содержаний кремния в перидотитах основной серии (слоя) указывает на линзовидную организацию мантии (см. рис. 4). В полном соответствии с общей моделью [Snyder, 2002], юго-западный край мантийного основания выступает далеко за видимый контур Сибирского кратона, подстилая обрамляющие его комплексы Центрально-Азиатского орогенного пояса.

\section{4. ЛИТОСФЕРНАЯ СТРУКТУРА ЮГО-ЗАПАДНОЙ ОКРАИНЫ СИБИРСКОГО КРАТОНА}

Используя концентрическую зональность мантийных перидотитов, а также содержания кремния в ксенолитах трубки Мир (см. рис. 4), можно наметить контуры мантийной линзы, расположенной под юго- западным краем Сибирского кратона (рис. 6). Последний, строго говоря, является суперкратоном, в фундаменте которого, в зависимости от детальности анализа, выделяют до 15 региональных блоков. Наиболее важные и резкие разделы оконтуривают 4-5 основных мегаблоков, положение которых практически совпадает на разных схемах [Mironyuk, Zagruzina, 1983; Mitrofanov, Taskin, 1994]. В фундаменте юго-западной части Сибирской платформы выделяется Ангарский мегаблок [Mironyuk, Zagruzina, 1983], расположенный над центральной частью предполагаемой мантийной линзы (рис. 6, А). Именно он отвечает верхней «коровой» части той литосферной структуры, глубинным основанием которой является мантийная линза. По концепции М.3. Глуховского [Glukhovsky, 1990], здесь расположен Ангарский нуклеар, в пределах которого формировалась кора Сибирского кратона на архейской стадии планетарной эволюции.

Сейсмические данные о структуре подкратонной мантии. Сложная структура фундамента Сибирского кратона согласуется с расположением высокоскоростных аномалий, обнаруженных на основе супердлинных профилей в сейсмическом эксперименте с мирными атомными взрывами [Pavlenkova G.A., Pavlen- 
kova N.I., 2006]. На схеме, построенной для глубины 60 км (рис. 6, B), с Анабарским и Тунгусским мегаблоками фундамента совпадают две аномалии в мантии, оконтуренные изолиниями скорости 8.3 км/с. Ангарскому мегаблоку отвечает главная сейсмическая аномалия Сибирского кратона, в пределах которой скорость волн превышает 8.4 км/с. Положение аномалии совпадает с центральной частью мантийной линзы. Именно в этом районе становятся крайне низкими концентрации кремния в перидотитах и, в соответствии с корреляциями, до максимальных значений возрастают содержания железа и магния - компонентов, определяющих высокую плотность мантийного вещества. Закономерно то, что центр мантийной линзы отличается самой высокой скоростью сейсмических волн, установленной для Сибирского кратона.

Результаты сейсмотомографического моделирования неоднородности мантии Сибирского кратона [Koulakov, Bushenkova, 2010] подтверждают закономерное положение высокоскоростной сейсмической аномалии в центре мантийной структуры (рис. $7, A$ ). Предполагаемая мантийная линза отвечает верхней части трубообразного корня кратона, который погружается на глубину свыше 600 км (рис. 7, В). Для среза 50 км сейсмотомографическая модель показывает постепенное возрастание скорости волн к центру мантийной структуры [Koulakov, Bushenkova, 2010], в соответствии с концентрической зональностью изменения состава мантии (рис. 7, А). Примечательно то, что в самом центре сейсмической аномалии скорость волн резко падает, что, по нашему мнению, может отражать химическую стратификацию мантии (рис. 7, B). При наклоне мантийных слоев к центру линзы скорость сейсмических волн в нем на горизонтальном срезе может отражать уже плотность перидотитов самого верхнего слоя мантии.

Важной характеристикой литосферной мантии является азимутальная анизотропия распространения сейсмических волн, связанная преимущественно с закономерной ориентировкой кристаллов оливина главного минерала мантийных перидотитов. Первые азимуты распространения быстрых волн для югозападной части Сибирского кратона были определены Л.П. Винником с соавторами [Vinnik et al., 1992] на станциях ELT, ZAK и IRK (рис. 7, A). Анализ сводных данных [San'kov et al., 2011], полученных за последние 20 лет для Алтае-Саянского региона, показал существование двух четко выраженных региональных максимумов анизотропии: главного - 310-320 тельного, менее четкого, 30-60 (рис. 7, A). Положение и структура мантийной линзы могут, по нашему мнению, играть определяющую роль в закономерностях анизотропии сейсмических волн. Во внутренних частях линзы ориентировка оливина может быть преимущественно реликтовой, «fossil» в понимании [Silver, Chan, 1991], и изменяться в соответствии с зональностью состава мантии. Векторы анизотропии в этом случае будут преимущественно выстраиваться по касательной к центру мантийной структуры. С этим фактором могут быть связаны как ориентировка главного регионального направления анизотропии (310-320 $)$, так и азимут быстрой оси волн на станции IRK (рис. 7 , A). Во внешних частях мантийной линзы оливин должен быть преимущественно переориентирован под действием внешних сжимающих напряжений. Векторы анизотропии должны располагаться перпендикулярно границе мантийной структуры. Этот фактор мог определить появление второго максимума сейсмической анизотропии [San'kov et al., 2011] и значения азимутов быстрых волн на станциях ELT, ZAK (рис. 7, A). Красноречивым примером предполагаемого распределения векторов быстрых волн в мантии Сибирского кратона является концентрический рисунок анизотропии, детально изученной для мантии западной части США [Savage, 1999].

Вполне возможно, что выступающий на юг глубинный край Сибирского кратона определял и определяет конфигурацию полей напряжений в мантии и, значит, ориентировку анизотропии во всей западной части Центрально-Азиатского пояса. По крайней мере, в более южной части орогенного пояса [Barruol et al., 2008] особенности сейсмической анизотропии, видимо, согласуются с положением литосферной линзы. Здесь быстрые оси сейсмических волн меняют ориентировку с СЗ-ЮВ направления в Центральной Монголии на СВ-ЮЗ направление далее к востоку.

Роль мантийной структуры в геодинамической эволюции. Огромная высокоплотная мантийная линза, поперечник которой составляет около 2000 км, несомненно, должна была влиять на процессы деформирования литосферы. Ее воздействие на тектоническую эволюцию легко обнаруживается тогда, когда рассматриваются наиболее общие и масштабные особенности регионального строения.

Становление офиолитовых комплексов поверх мантийного края кратона в рифее - начале кембрия завершило окраинноморский рифтогенез на окраине Сибирского континента [Didenko et al., 1994; Pechersky, Didenko, 1995]. В последующем закрытии Палеоазиатского океана главную роль играла аккреция перемещенных палеозойских океанических и островодужных блоков к континентальной окраине [Şengör, Natal'in, 1996; Xiao et al., 2010]. Именно мантийная линза, как показывает кругообразный изгиб общего простирания главных палеозойских субдукционно-аккреционных комплексов (рис. 8, A), определяла конфигурацию окраины Сибирского палеоконтинента. Зоны полномасштабной субдукции, разделявшие сибирские и гондванские блоки, очевидно, не могли находиться севернее глубинной границы кратона. Анализ данных по тектонике и магматизму показывает [Glorie et al., 2011], что на западе региона ближайшая к Сибирскому палеоконтиненту кембрийская зона субдукции располагалась к югу от Горного Алтая вдоль скрытого ман- 

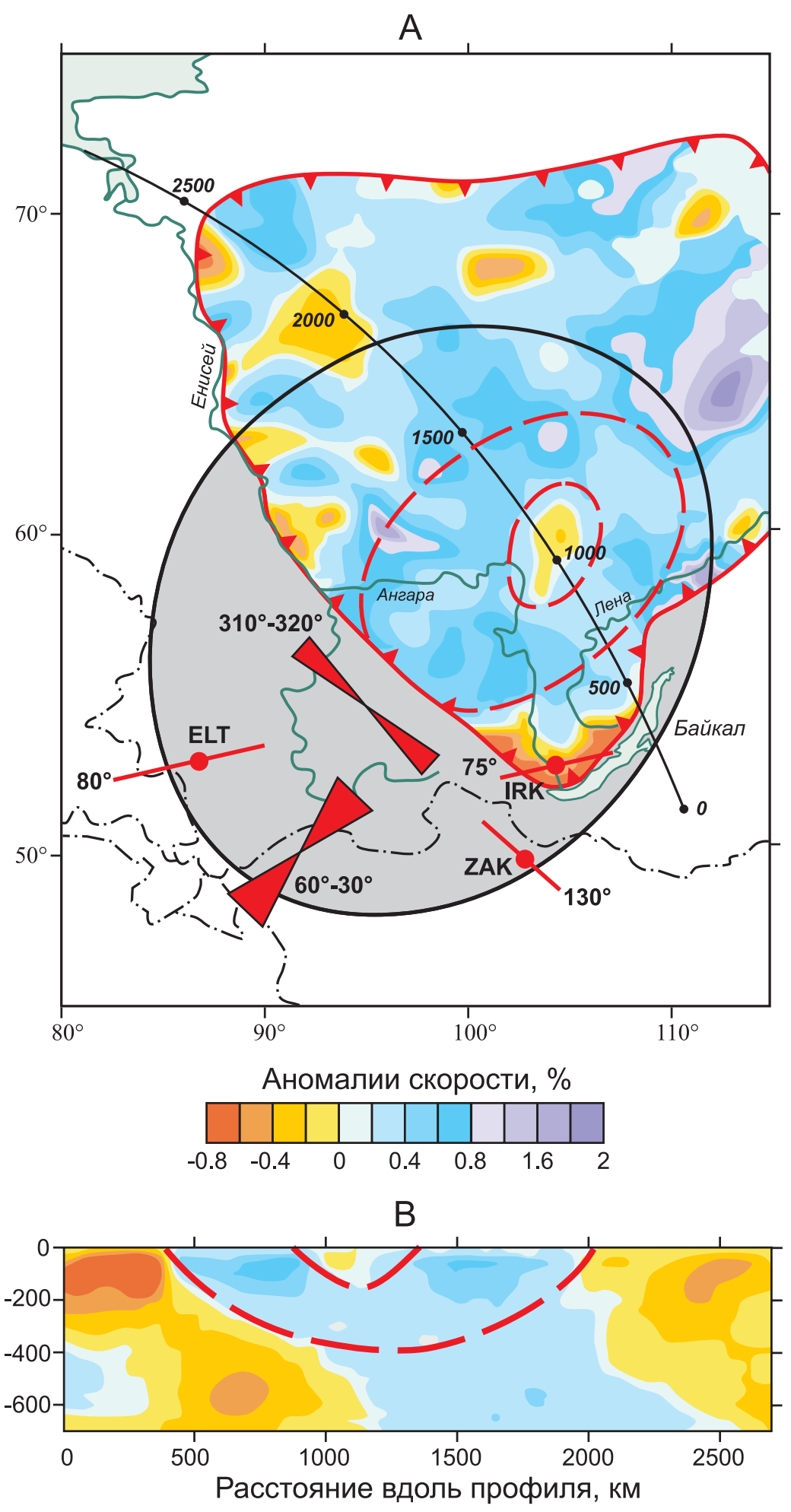

Рис. 7. Структура литосферной мантии юго-западной части Сибирского кратона по сейсмологическим данным.

A - сейсмотомографическая модель верхней мантии для глубины 50 км [Koulakov, Bushenkova, 2010]. Красным цветом показаны направления сейсмической анизотропии в верхней мантии для станций ZAK, ELT, IRK, по [Vinnik et al., 1992], усредненные векторы анизотропии, по [San'kov et al., 2011]; B - разрез скоростной структуры подкратонной мантии вдоль профиля на рис. 7, A, по [Koulakov, Bushenkova, 2010]. Красным пунктиром показан предполагаемый контур мантийной линзы.

Fig. 7. The structure of the lithospheric mantle of the south-western part of the Siberian craton from seismological data.

A - the seismotomographic model of the upper mantle to a depth of $50 \mathrm{~km}$ [Koulakov, Bushenkova, 2010]. Red - directions of seismic anisotropy in the upper mantle for ZAK, ELT, and IRK Stations according to [Vinnik et al., 1992]. Average anisotropy vectors are shown according to [San'kov et al., 2011]; B - a cross-section of the velocity structure of the sub-cratonic mantle along the profile shown in Fig. 7, A, according to [Koulakov, Bushenkova, 2010]. The red dashed line shows the estimated contour of the mantle lense. 

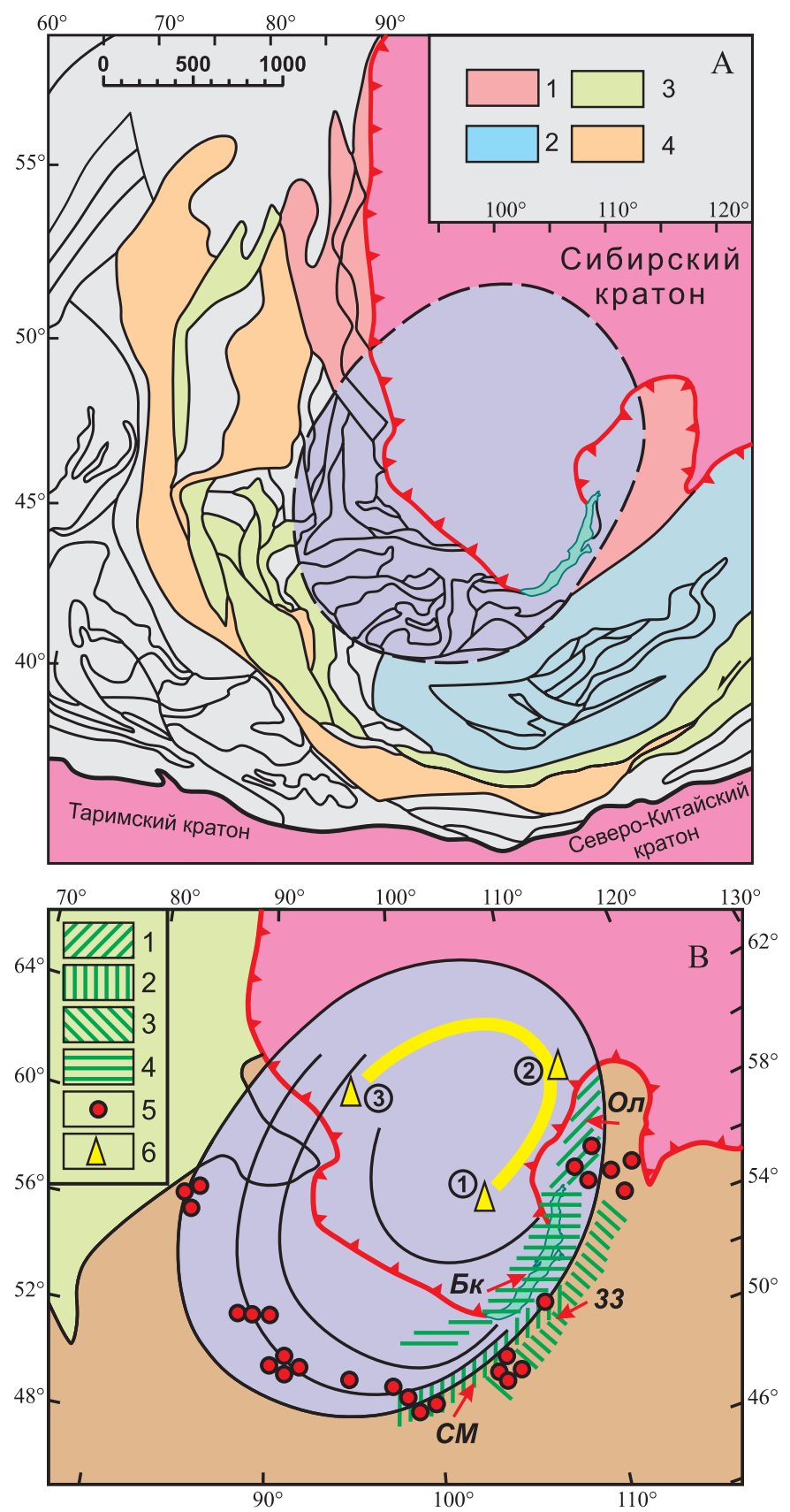

Рис. 8. Влияние мантийного края Сибирского кратона на тектоническую эволюцию северо-западной части ЦентральноАзиатского складчатого пояса.

Положение мантийной линзы показано сиреневым цветом, граница Сибирского кратона в структуре верхней части коры обозначена красной линией со штрихами. A - кругообразная конфигурация комплексов алтаид у края Сибирского палеоконтинента. 1 - байкалиды; 2 - Тувино-Монгольский массив; субдукционно-аккреционные комплексы палеозоя: 3 - кембрия-силура, 4 - девона-перми, по [Şengör, Natal'in, 1996; Xiao et al., 2010]; B - положение областей растяжения у мантийного края Сибирского кратона. 1-4 - рифтовые зоны: 1 Олокитская (рифей) [Rytsk et al., 2002], 2, 3 - Северо-Монгольская (поздняя пермь - ранний триас) и Западно-Забайкальская (средний триас - поздний триас), по [Yarmolyuk et al., 1997], 4 - Байкальская (кайнозой); 5 - интрузии субщелочных и щелочных габброидов и расслоенные габбро-норит-ортопироксенитовые массивы; 6 - желтым цветом подчеркнута зона, в которой расположены нефтегазовые супергиганты Лено-Тунгусской провинции: 1 - Ковыктинское, 2 - Чаяндинское и 3 - Юрубчено-Тахомское месторождения.

Fig. 8. The influence of the mantle edge of the Siberian craton on the tectonic evolution of the north-western part of the Central Asian fold belt.

The position of the mantle lense is shown in purple; the boundary of the Siberian craton in the structure of the upper crust is shown by the red line with strokes. A - circular configuration of the Altaid series at the edge of the Siberian paleocontinent. 1 - Baikalides; 2 - Tuva-Mongolia massif; the Palaeozoic subduction-accretion complexes: 3 - Cambrian-Silurian, 4 - Devonian-Permian, according to [Şengör, Natal'in, 1996; Xiao et al., 2010]; B - positions of stretching areas at the mantle edge of the Siberian craton. 1-4 - rift zones: 1 - Olokit (Riphean) [Rytsk et al., 2002], 2 North-Mongolian (Late Permian to Early Triassic), 3 - West Transbaikalian (Middle Triassic to Late Triassic), according to [Yarmolyuk et al., 1997], 4 - Baikal (Cenozoic); 5 - sub-alkaline and alkaline intrusions and layered gabbronorite-orthopyroxenite massifs; 6 - the area highlighted in yellow comprises super-gigantic fields of oil and gas in the Lena-Tunguska province: 1 - Kovykta, 2 - Chayanda, 3 - Yurubcheno-Takhoma. 


\section{Т а б л и ц а 2. Циклы сильных землетрясений анализируемых сейсмических зон Азии}

T a b l e 2. Cycles of strong earthquakes of analyzed seismic zones of Asia

\begin{tabular}{|c|c|c|c|c|c|c|}
\hline \multirow[t]{2}{*}{ № } & \multirow[t]{2}{*}{ Название } & \multirow[t]{2}{*}{ Дата } & \multicolumn{2}{|c|}{ Эпицентр } & \multirow[t]{2}{*}{ Глубина, км } & \multirow[t]{2}{*}{ Магнитуда, М } \\
\hline & & & Широта & Долгота & & \\
\hline \multicolumn{7}{|c|}{ 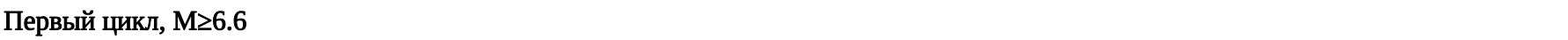 } \\
\hline 1 & & 12.01.1885 & 52.5 & 106.5 & 25 & 6.7 \\
\hline 2 & & 11.04.1902 & 51.6 & 104.5 & 16 & 6.6 \\
\hline 3 & Байкальское & 26.11.1903 & 52.7 & 107.6 & 30 & 6.7 \\
\hline 4 & Цэцэрлэгское & 09.07.1905 & 49.5 & 97.3 & 22 & 7.6 \\
\hline 5 & Болнайское & 23.07.1905 & 49.3 & 96.2 & 25 & 8.2 \\
\hline 6 & & 29.04.1917 & 56.0 & 113.8 & 18 & 6.6 \\
\hline 7 & Монголо-Алтайское & 10.08.1931 & 46.5 & 90.5 & 40 & 7.8 \\
\hline \multicolumn{7}{|c|}{$\begin{array}{l}\text { Байкальская сейсмическая зона, 1885-1931 гг. } \\
\text { Приамурская и Приморская сейсмические зоны, 1888-1924 гг. }\end{array}$} \\
\hline \multicolumn{7}{|c|}{ 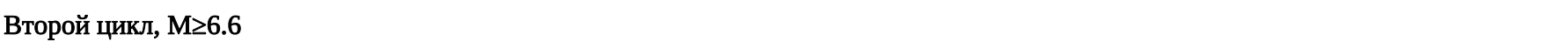 } \\
\hline 8 & Мондинское & 04.04 .1950 & 51.77 & 101.00 & 20 & 7.0 \\
\hline 9 & Муйское & 27.06.1957 & 56.2 & 116.4 & 15 & 7.6 \\
\hline 10 & Гоби-Алтайское & 04.12 .1957 & 45.1 & 99.4 & 25 & 8.1 \\
\hline 11 & Среднебайкальское & 29.08.1959 & 52.68 & 106.98 & 20 & 6.8 \\
\hline 12 & Могодское & 05.01.1967 & 48.1 & 102.9 & 25 & 7.8 \\
\hline \multicolumn{7}{|c|}{$\begin{array}{l}\text { Байкальская сейсмическая зона, 1950-1967 гг. } \\
\text { Приамурская и Приморская сейсмические зоны, 1942-1973 гг. }\end{array}$} \\
\hline \multicolumn{7}{|c|}{ Третий цикл, $\mathrm{M} \geq 6.3$} \\
\hline 13 & Бусийнгольское & 27.12.1991 & 51.02 & 98.15 & 13 & 6.4 \\
\hline 14 & Алтайское & 27.09 .2003 & 50.04 & 87.81 & 16 & 7.3 \\
\hline 15 & & 27.09.2003 & 50.09 & 87.76 & 10 & 6.4 \\
\hline 16 & & 01.10 .2003 & 50.21 & 87.72 & 10 & 6.7 \\
\hline 17 & & 27.08.2008 & 51.61 & 104.16 & 16 & 6.3 \\
\hline 18 & & 27.12.2011 & 51.84 & 95.91 & 15 & 6.6 \\
\hline 19 & & 26.02.2012 & 51.73 & 95.92 & 11 & 6.7 \\
\hline
\end{tabular}

П р и м е ч а н и е. Параметры землетрясений приводятся в соответствии с «Новым каталогом сильных землетрясений на территории СССР» [Kondorskaya, Shebalin, 1977] для 1880-1974 гг. и Базой данных Национального информационного центра по землетрясениям Геологической службы США [http://neic.usgs.gov] для 1973-2012 гг., сейсмические циклы Приамурской и Приморской зон - по [Stepashko, 2010, 2011a].

N o t e. Earthquake parameters are given according to the USSR Catalog of Strong Earthquakes [Kondorskaya, Shebalin, 1977] for the period from 1880 to 1974 and data from the National Earthquake Information Center (NEIC) of the U.S. Geological Survey (http://neic.usgs.gov) for the period from 1973 to 2012. Seismic cycles of the Amur and Primorskaya zones are given according to [Stepashko, 2010, 2011a].

тийного края кратона.

При процессах регионального растяжения погруженные краевые части мантийной структуры должны быть наиболее благоприятны для деструкции литосферы. К северо-востоку от Байкала (рис. 8, B), вдоль границы подкратонной линзы, протягивается на 250 км линейная Олокитская зона рифтогенеза среднего-позднего рифея [Rytsk et al., 2002]. Южнее, также обрамляя мантийную линзу, расположены Северо-Монгольская и Западно-Забайкальская рифтогенные зоны, образование которых последовательно произошло в перми и триасе [Yarmolyuk et al., 1997]. С рифтогенезом связано образование глубинных расплавов щелочных и субщелочных габброидов, а также становление расслоенных габбро-норит-ортопироксеновых плутонов. Абсолютное большинство магматических интрузий этих типов сосредоточено в изогнутой полосе от Кузнецкого Ала- тау на западе до русла р. Витим на востоке (рис. 8, B). Наблюдаемое соответствие предполагает, что образование мантийных расплавов, отражающих глубинное растяжение, контролируется скрытой мантийной границей Сибирского кратона.

В северной части литосферной линзы в пределах Сибирского кратона важным отражением рифтогенеза являются нефтегазовые месторождения Лено-Тунгусской провинции [Kontorovich et al., 2009; Surkov et al., 1996]. Нефтегазоносность здесь связана, прежде всего, с терригенно-карбонатными отложениями венд-рифейского возраста, с периодом, когда условия растяжения господствовали и на южной окраине Сибирского кратона. Заслуживает внимания то, что супергигантские месторождения Восточной Сибири (Чаяндинское, Ковыктинское, Юрубчено-Тахомское) расположены на близком расстоянии от центра мантийной структуры 
(рис. 8, B). Возможно, именно ее воздействие являлось тем глубинным фактором, который определил как региональные следствия рифтогенеза (от вариаций температурного режима до проницаемости недр), так и особенности размещения структур, наиболее благоприятных для накопления углеводородов.

Осадочные впадины, фиксирующие юго-западный фланг Байкальской сейсмической зоны кайнозойского рифтогенеза, также сосредоточены вдоль погребенного края мантийной линзы (рис. 8, В). Эта связь подчеркнута котловиной озера Байкал, которая ориентирована вдоль простирания зональности мантии (рис. 8, Б). Вовлеченность скрытого основания кратона в региональные деформации на кайнозойском этапе определенно предполагает прямое участие мантийной структуры в генезисе Байкальской сейсмической зоны.

\section{5. ВЗАИМОДЕЙСТВИЕ ДЕФОРМАЦИОННЫХ ВОЛН С ЛИТОСФЕРНОЙ СТРУКТУРОЙ В БАЙКАЛЬСКОЙ СЕЙСМИЧЕСКОЙ ЗОНЕ}

Самым красноречивым отражением волновой природы сейсмичности в Байкальской зоне является регулярная цикличность сильных землетрясений (табл. 2). Для последних 130 лет они группируются в три сейсмических цикла: граница XIX и XX вв., середина прошлого века и граница XX и XXI вв. Эти же циклы сильных землетрясений наблюдаются на Дальнем Востоке России, в Приморской и Приамурской зонах (табл. 2), причем направления сейсмической миграции на Дальнем Востоке точно указывают на то, что деформационные волны приходят с запада [Stepashko, $2010,2011 a]$. Согласованность байкальской и дальневосточной ритмики предполагает, что раз в 50 лет вдоль северной границы Центрально-Азиатского орогенного пояса с запада на восток проходят деформационные волны, которые образуются, по всей видимости, в результате сжатия в Памиро-Гиндукушском узле области коллизии Индийской и Евроазиатской плит [Ivanova, Trifonov, 2005; Malamud, Nikolaevsky, 1983, 1985].

Взаимодействие волны деформаций с мантийным основанием Сибирского кратона. Самый общий тектонофизический подход предполагает, что, перемещаясь в мантии из района Памира в северо-восточном направлении, деформационная волна сталкивается с глубинным основанием Сибирского кратона и реагирует на эту преграду, отдавая ей часть своей энергии. В этом случае над местом столкновения должна возникать область деформирования и деструкции, которая может охватывать весь разрез литосферы (рис. 9, $A$ ). В соответствии с положениями механики, энергия деформационной волны и сжатие, которое она вызывает, должны перераспределяться по двум направлениям (рис. 9, B): по радиусу к центру мантийной линзы и по касательной к ее границе. Эти особенности взаимодей- ствия должны находить отражение в региональном поле напряжений, определяя общий характер сейсмичности.

Предполагаемая область деформаций обнаруживается в распределении эпицентров землетрясений последнего цикла (табл. 2). Все они, начиная с Бусийнгольского толчка 1991 г. и заканчивая недавними землетрясениями в Туве в 2011 и 2012 гг. (рис. 9, C), образуют полосу, которая протягивается субширотно от Байкала до Алтая на расстояние порядка 2000 км. Ее положение прямо не связано ни с каким тектоническим нарушением. Этот сейсмический шов (удобно называть его Байкало-Алтайским) маркирует скрытую зону деформаций, которая расположена по касательной к концентрической структуре подкратонной мантии (рис. 9, C). Смещенность ее к северу относительно глубинной границы в плане объясняется уменьшением поперечника мантийной линзы с ростом глубины (рис. 9, А). Второе предполагаемое направление сжатия, ориентированное к центру мантийной структуры (рис. $9, B)$, обнаруживается в миграции самых сильных землетрясений цикла поперек сейсмического шва (рис. 9, C). Эпицентр первого Бусийнгольского землетрясения 1991 г. занимает самое южное положение, а тувинские события 2011 и 2012 гг. находятся на севере сейсмического шва. Как и предполагаемый вектор сжатия (рис. $9, B$ ), траектория миграции землетрясений ориентирована с юга на север.

Аналогичный сейсмический шов образуют землетрясения первого цикла, которые произошли на границе XIX и XX вв. (табл. 2). Эпицентры событий (рис. 9, $C)$, начиная с толчка 1885 г. и заканчивая МонголоАлтайским землетрясением 1931 г., укладываются в полосу, смещенную на юго-восток относительно первого сейсмического шва. Ориентировка ее также изменяется, подчиняясь постепенной смене простирания мантийной структуры. Сильные землетрясения в пределах второго сейсмического шва (его можно назвать Байкало-Монгольским), как и в первом случае, мигрируют поперечно (рис. 9, C), но уже в обратном - южном - направлении, от центра мантийной линзы. Рабочее объяснение предполагает (рис. 9, $A, B$ ), что деформационная волна частично проникает в пределы подкратонной мантии, отражается там и разворачивается в юго-восточном направлении. Взаимодействие волны деформаций с границей мантийной линзы происходит в этом случае дважды, на входе и на выходе из нее.

В соответствии с рабочей моделью (рис. 9, В), под действием волны деформаций должен возникать второй вектор сжатия, ориентированный продольно вдоль зон деформаций. С учетом траектории волны, в обоих сейсмических швах, как в Байкало-Алтайском, так и в Байкало-Монгольском, он ориентирован в восточном направлении. В этом направлении должна возникать соответствующая продольная сейсмическая миграция, по касательной к концентрической мантийной структуре. Такая миграция землетрясений с запада на 

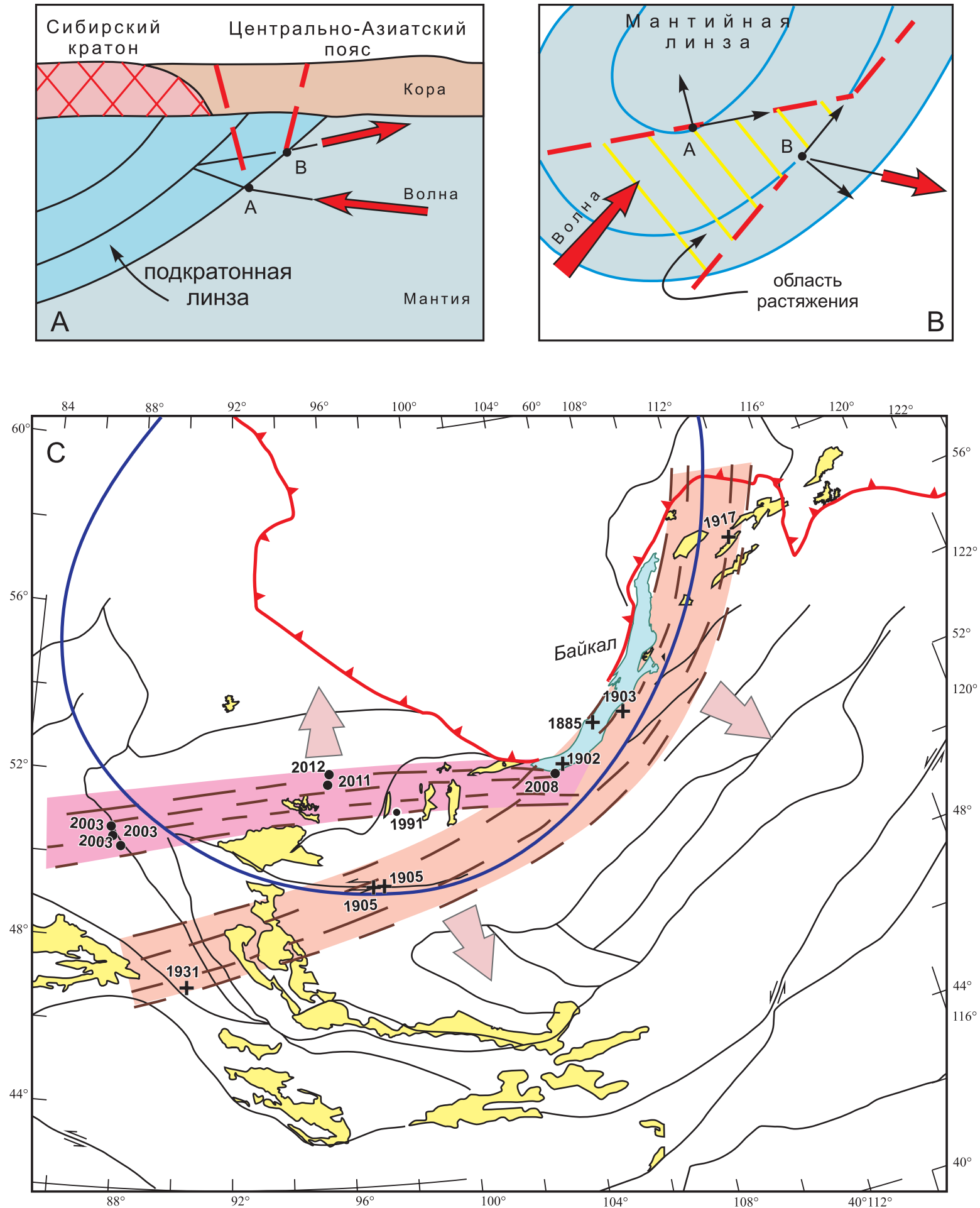

Рис. 9. Взаимодействие деформационной волны с мантийным основанием Сибирского кратона.

$A$ - образование двух зон деформаций над точками (А) и (В) у границы мантийной линзы; $B$ - швы сжатия и область растяжения между ними, образовавшиеся под воздействием деформационной волны над краем мантийной линзы; $C$ - сейсмические швы Байкальской зоны. Точки и крестики - эпицентры сильных землетрясений двух циклов (табл. 2). Большие стрелки показывают направления сжатия и поперечной сейсмической миграции в швах. Рифтовые впадины: Тункинская, Хубсугульская, Дархатская, Бусийнгольская, Убсунурская и другие показаны желтым цветом. Фиолетовая линия - граница мантийной линзы Сибирского кратона.

Fig. 9. Interaction between the deformation wave and the mantle basement of the Siberian craton.

$A$ - formation of two zones of deformation above points (A) and (B) at the boundary of the mantle lense; $B$ - compression sutures separated by the stretching area, which formed under the influence of the deformation wave above the edge of the mantle lense; $C$ - seismic sutures of the Baikal zone. Dots and crosses show epicentres of strong earthquakes that occurred in two cycles (see Table 2). Large arrows show directions of compression and transverse seismic migration. Rift valleys (Tunka, Khubsugul, Darkhat, Busiyngol, Ubsunur etc.) are shown in yellow. The purple line shows the boundary of the mantle lense of the Siberian craton. 


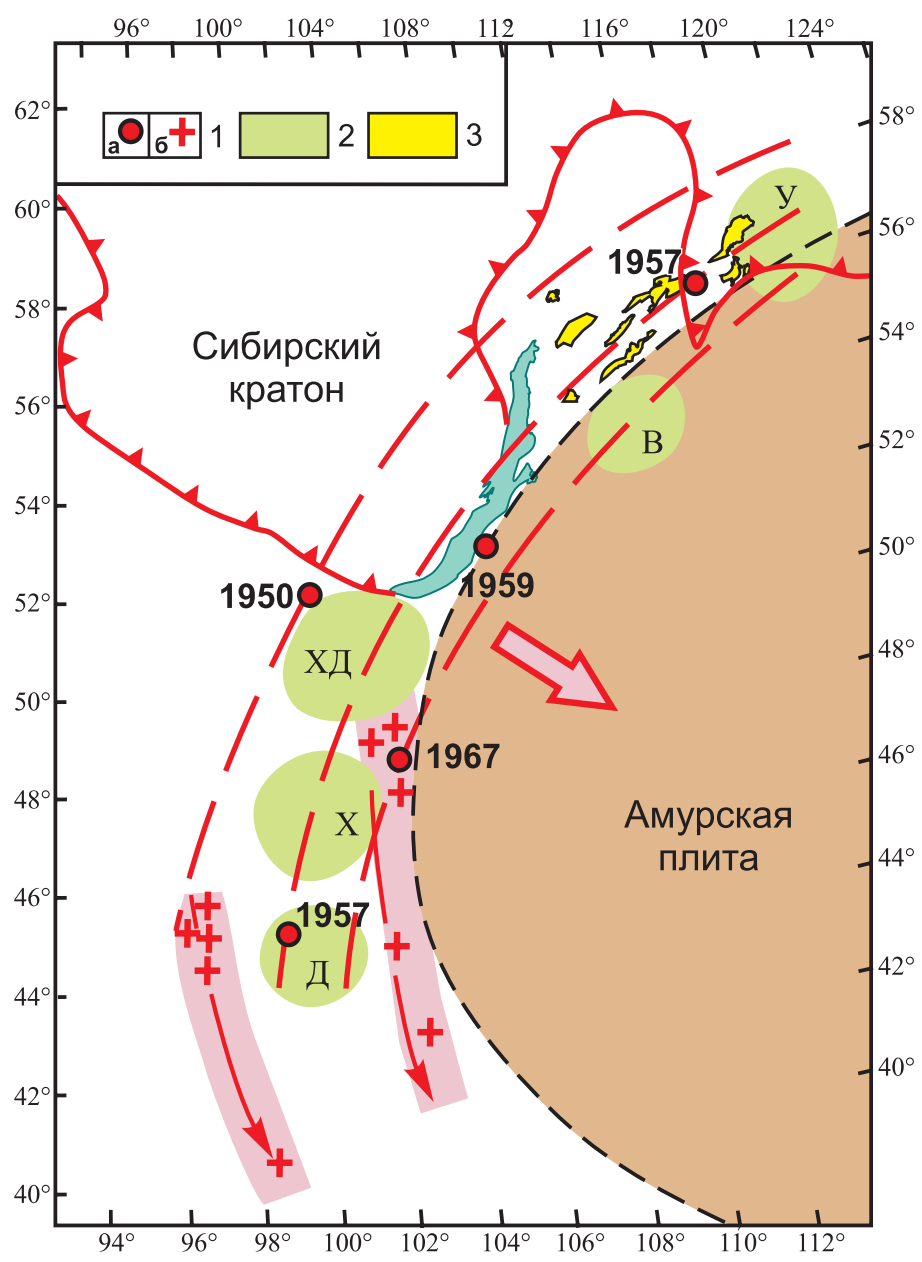

Рис. 10. Ортогональная миграция сейсмичности в Западно-Амурском сейсмическом шве.

Кружки - эпицентры и годы землетрясений магнитудой $\mathrm{M} \geq 6.6$ второго цикла (табл. 2). Большая стрелка - направление поперечной миграции сильных землетрясений. Крестики - положение эпицентров землетрясений магнитудой $\mathrm{M} \geq 5.0$ за последние 40 лет в районе с координатами $50-40^{\circ}$ с.ш. и $94-104^{\circ}$ в.д. (табл. 3). Стрелки - направления продольной миграции землетрясений в южной части сейсмического шва. Зеленым цветом показано положение полей кайнозойских щелочных базальтов. Граница Амурской плиты по [Zonenshain, Savostin, 1979].

Fig. 10. Orthogonal migration of seismicity in the West Amur seismic suture.

Epicentres and years of earthquakes ( $M \geq 6.6$, Cycle 2, see Table 2) are shown at the circles. The large arrow shows the direction of transverse migration of strong earthquakes. Crosses show positions of epicentres $(M \geq 5.0)$ for the past 40 years in the region with the following coordinates: $50-40^{\circ} \mathrm{N}, 94-104^{\circ} \mathrm{E}$ (see Table 3). Arrows show directions of longitudinal migration of earthquakes in the southern segment of the seismic suture. Fields of the Cenozoic alkaline basalts are shown in green. The boundary of the Amur plate is given according to [Zonenshain, Savostin, 1979].

восток на ЮЗ фланге Байкальской сейсмической зоны обнаружена для событий с магнитудой $\mathrm{M} \geq 4.4$, которые произошли в период с 1950 по 2008 г. [Sherman, Gorbunova, 2010; Sherman, Zlogodukhova, 2011].

Противоположные направления поперечного сжа- тия в двух сейсмических швах, с юга на север в Байкало-Алтайском и с севера на юг в Байкало-Монгольском, должны обязательно приводить к постоянному растяжению ограниченной швами треугольной области. Именно в ней расположены кайнозойские осадочные впадины, от Тункинской и Хубсугульской на востоке до Убсунурской на западе (см. рис. 9, C), которыми отмечена область максимального проявления рифтогенных процессов [Logachev, 2003]. Следовательно, рифтогенез и его сейсмичность, имея общий генезис, по-разному отражают взаимодействие деформационной волны с мантийным краем Сибирского кратона.

Столкновение волны деформаций с границей Амурской плиты. Изменив траекторию после столкновения с мантийным основанием Сибирского кратона, деформационная волна уходит в юго-восточном направлении. Сильные землетрясения, объединенные во второй цикл (см. табл. 2), позволяют определить возникающие при этом сейсмодинамические следствия. Эпицентры толчков, которые произошли с 1950 г. по 1967 г., укладываются в широкую изогнутую полосу (рис. 10), маркируя еще один сейсмический шов Байкальской зоны. Он протягивается вдоль западной границы Амурской плиты [Zonenshain, Savostin, 1979], положение которой подчеркнуто известной цепочкой полей кайнозойского щелочно-базальтового вулканизма, от Удокана на северо-востоке до Долиноозерского ареала на юго-западе. Этот шов может быть назван Западно-Амурским. Для него также характерна поперечная миграция сильных землетрясений, эпицентры которых смещаются с запада на восток (рис. 10), указывая на ориентировку главного вектора сжатия в направлении, перпендикулярном границе Амурской плиты.

Если образование сейсмического шва по границе Амурской плиты вызвано деформационной волной (см. рис. 9, B), то, кроме поперечного сжатия, в соответствии с общим механизмом должно возникать дополнительное сжатие, ориентированное вдоль шва. Продольная миграция землетрясений на северо-восточном фланге Байкальской сейсмической зоны известна [Sherman, 2009; Sherman, Zlogodukhova, 2011]. Эпицентры толчков с магнитудой $\mathrm{M} \geq 4.4$ в последние 60 лет здесь мигрировали с востока на запад (рис. 11, A). Сжимая Амурскую плиту в восточном направлении, деформационная волна, видимо, закручивает ее одновременно против часовой стрелки. В этом случае продольная миграция землетрясений должна наблюдаться не только в северной части сейсмического шва к северо-востоку от Байкала, но и в его южной части, на территории Монголии (см. рис. 10). В соответствии с принятыми допущениями, продольная миграция землетрясений здесь должна проходить не с востока на запад, а с севера на юг.

Судя по мировой базе данных NEIC.USGS, в области, ограниченной координатами $50-40^{\circ}$ с.ш. и 94-104 в.д. (см. рис. 10), за последние 40 лет произошло 10 землетрясений с магнитудой $M \geq 5.0$ (табл. 3). Законо- 

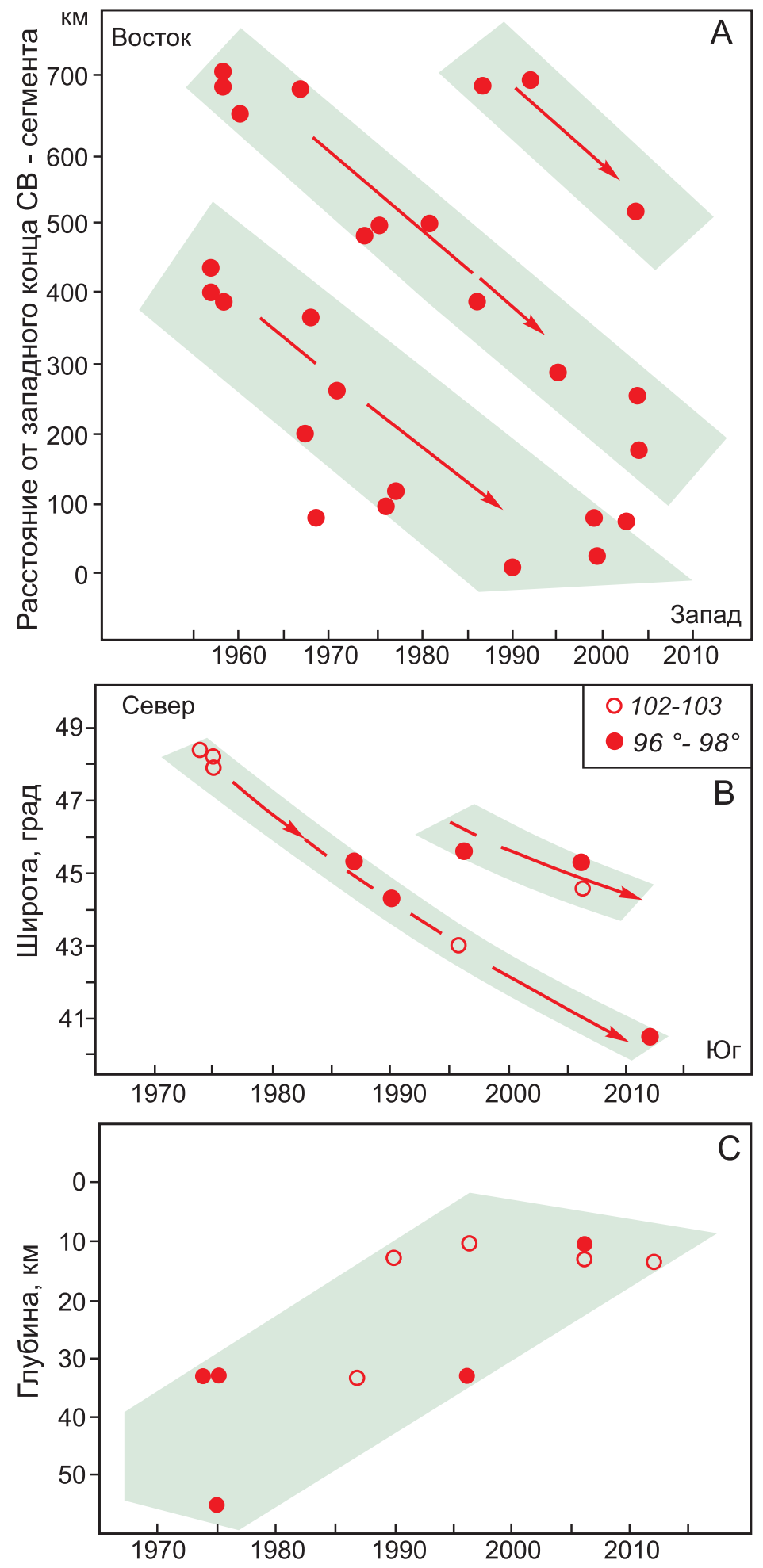

Рис. 11. Особенности продольной сейсмической миграции вдоль западной границы Амурской плиты.

$A$ - субширотная миграция землетрясений с магнитудой $\geq 4.4$ в северо-восточном сегменте Байкальской зоны, перестроенный график работы [Sherman, Zlogodukhova, 2011], с упрощениями. По вертикальной оси - расстояние от западного окончания сегмента. $B$ - субмеридиональная миграция землетрясений с магнитудой $\geq 5.0$ в южной части Байкальской зоны, район с координатами 40-50 в.д.; залитые и незалитые кружки - толчки двух разных зон (рис. 10). С - уменьшение глубины гипоцентров землетрясений с М $\geq 5.0$ в южной части Байкальской зоны.

Fig. 11. Specific features of longitudinal seismic migration along the western boundary of the Amur plate.

$A$ - sublatitudinal migration of earthquakes $(\mathrm{M} \geq 4.4)$ in the north-eastern segment of the Baikal zone; the curve from [Sherman, Zlogodukhova, 2011] is revised and simplified. Vertical axis - distances from the western termination of the segment. $B$ - submeridional migration of earthquakes $(\mathrm{M} \geq 5.0)$ in the southern part of the Baikal zone, coordinates of the area: $40-50^{\circ} \mathrm{N}, 94-104^{\circ} \mathrm{E}$; filled and unfilled circles show seismic shocks in two different zones (see Fig. 10). $C$ - reduction in depths of hypocentres of earthquakes (M $\geq 5.0$ ) in the southern part of the Baikal zone. 
A.A. Stepashko: The structure of the lithospheric mantle of the Siberain craton...

Т а б л и ц а 3. Параметры землетрясений магнитудой $\mathrm{M} \geq 5.0$ на юге Байкальской зоны, район с координатами 40-50 с.ш., 96-104ㅜ в.д.

$\mathrm{T}$ a $\mathrm{b}$ l e 3 . Parameters of earthquakes $(\mathrm{M} \geq 5.0)$ in the southern part of the Baikal zone (coordinates: $40-50^{\circ} \mathrm{N}, 96-104^{\circ} \mathrm{E}$ )

\begin{tabular}{llllll}
\hline \multirow{2}{*}{ № } & Дата & \multicolumn{2}{l}{ Эпицентр } & \multirow{2}{*}{ Глубина, км } & Магнитуда, М \\
\cline { 3 - 4 } & & Широта & Долгота & 33 & 5.1 \\
\hline 1 & 18.12 .1974 & 48.40 & 103.11 & 55 & 5.2 \\
2 & 27.10 .1975 & 48.22 & 102.69 & 33 & 5.4 \\
3 & 09.11 .1975 & 47.97 & 102.97 & 33 & 5.0 \\
4 & 28.01 .1987 & 45.36 & 96.14 & 12 & 5.2 \\
5 & 26.11 .1990 & 44.30 & 97.52 & 33 & 5.1 \\
6 & 07.02 .1996 & 42.96 & 103.00 & 12 & 5.0 \\
7 & 01.08 .1996 & 45.59 & 97.31 & 10 & 5.0 \\
8 & 15.06 .2006 & 45.37 & 97.44 & 13 & 5.2 \\
9 & 07.07 .2006 & 44.55 & 102.35 & 98.57 & \\
\hline
\end{tabular}

П р и м е ч а н и е. Параметры землетрясений по данным Национального информационного центра по землетрясениям Геологической службы США [http://neic.usgs.gov].

$\mathrm{N}$ o t e. Earthquake parameters are given according to data from the National Earthquake Information Center (NEIC) of the U.S. Geological Survey (http://neic.usgs.gov).

мерное изменение широты их эпицентров (рис. 11, B) отражает миграцию сейсмичности в южном направлении. На графике выделяются две серии событий, последняя из которых началась в 90-е годы. Она соответствует аналогичной небольшой серии землетрясений на северо-востоке Байкальской сейсмической зоны (рис. $11, A$ ). Главная серия южной части включает толчки, которые происходили на протяжении последних 40 лет, вплоть до настоящего времени (рис. 11, B). В действительности, она объединяет землетрясения, эпицентры которых сосредоточены в двух меридиональных подзонах (см. рис. 10). С учетом пространственных параметров, на юге выделяются две одновозрастных и продолжительных миграционных серии. Две аналогичных серии, которые начались в пятидесятые годы и продолжаются уже в XXI в., установлены и на северо-востоке сейсмического шва (рис. $11, A$ ). Видимо, продольная миграция землетрясений происходит согласованно вдоль всей активизированной западной границы Амурской плиты.

Две узких зоны, которые объединяют землетрясения с $M \geq 5.0$ в южной части региона (см. рис. 10), очевидно, приурочены к границам сейсмического шва, расположенного вдоль окраины Амурской плиты. При продольной миграции здесь закономерно меняется не только широта землетрясений, но и глубина их гипоцентров (рис. 11, C). Первые толчки здесь фиксируются в нижней части коры на глубине 60-30 км, последние - в верхней части, на глубине меньше 20 км. Миграция, таким образом, происходит не только в направлении с севера на юг, но и снизу вверх, что подчеркивает связь сейсмичности с деформационными процессами, происходящими в подкоровой части литосферы.

\section{6. К СЕЙСМОДИНАМИКЕ БАЙКАЛЬСКОЙ ОБЛАСТИ ДЕСТРУКЦИИ}

Ритмика сейсмичности. Генетическая связь Байкальской сейсмической зоны с волновыми деформациями нагляднее всего отражена в регулярной цикличности самых сильных землетрясений (см. табл. 2). Эта же ритмика наблюдается для более слабых толчков. Так, миграционные последовательности землетрясений с магнитудой $\mathrm{M} \geq 4.4$ в Западно-Амурском шве образовались в циклы сильных землетрясений середины и конца прошлого века. Общий уровень сейсмической активности в том или ином районе также, видимо, подчиняется предполагаемой волновой ритмике. Например, расчеты сейсмического момента для землетрясений с магнитудой 2.0-6.7 показали [Rundquist et al., 1999], что сейсмичность на северо-востоке Байкальской зоны с 1962 по 1991 г. была значительно выше, чем на ее юго-западном фланге. Самые сильные землетрясения с магнитудой 6.8-7.8 цикла середины века также произошли только в Западно-Амурском шве.

Особенностью Байкальской зоны является переменная активность, когда в каждом из циклов самые сильные землетрясения происходят только в одном из трех сейсмических швов. Возможно, что сжатия, которое накапливается в продолжение одного цикла, просто недостаточно для генерации сильного землетрясения. Исходя из траектории деформационной волны, можно предполагать, что первым должен активизироваться Байкало-Алтайский шов, затем Байкало-Монгольский, потом Западно-Амурский шов (рис. 12). Если 50-летний цикл выдерживается, то эта последовательность должна повторяться примерно через 150 лет. 


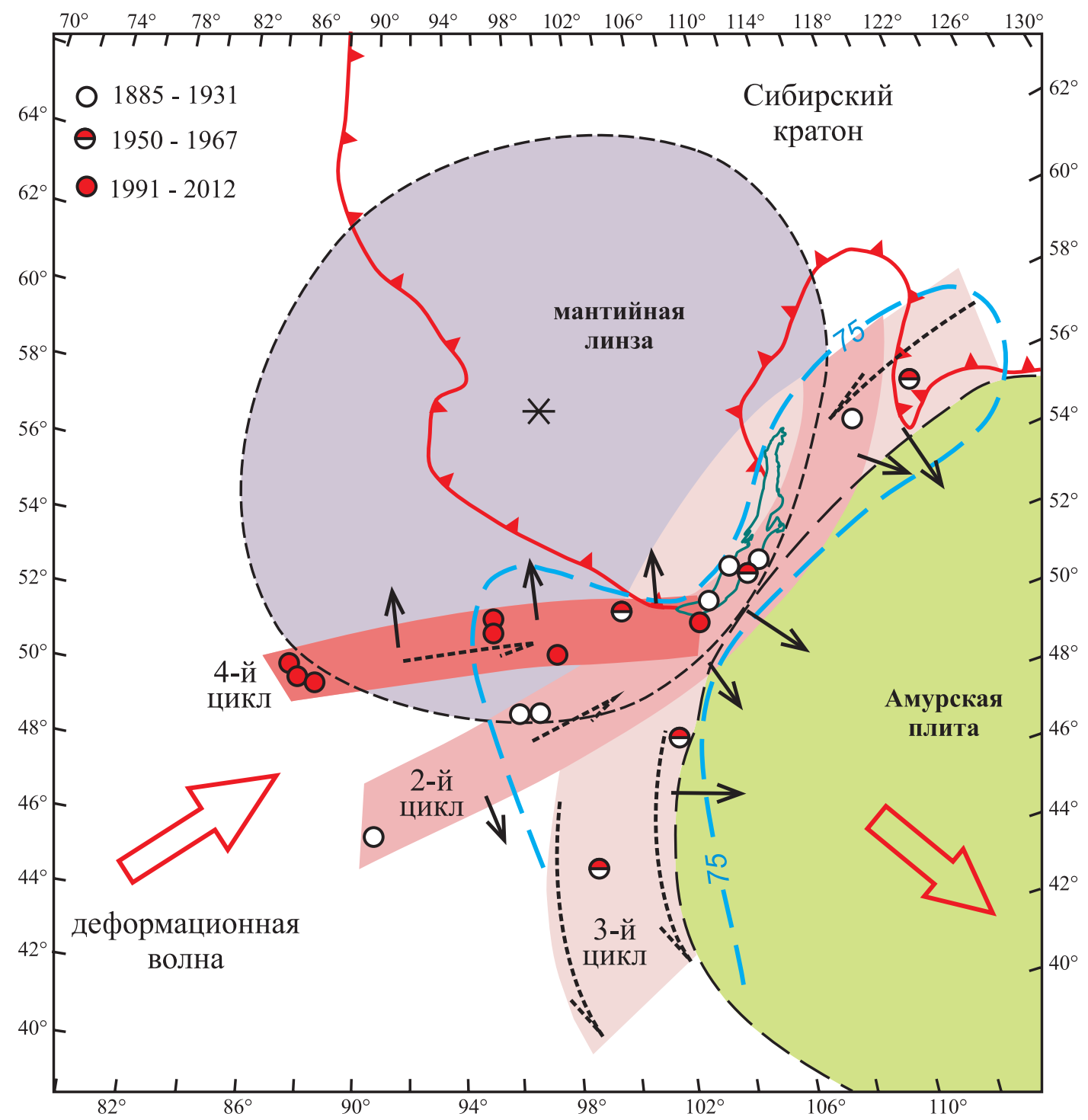

Рис. 12. Сейсмодинамическая модель Байкальской сейсмической зоны, расположенной на границе мантийной линзы Сибирского кратона и Амурской плиты.

Выделены цветом сейсмические швы, в которых сосредоточены землетрясения трех сейсмических циклов. Большие стрелки отмечают траекторию деформационной волны до и после взаимодействия с мантийной структурой. Сплошные стрелки - направления поперечной миграции землетрясений, пунктирные - продольной миграции землетрясений. Синей линией показаны контуры аномальной мантии, изолиния глубины литосферы 75 км приведена по [Zorin, Turutanov, 2005].

Fig. 12. The seismodynamic model of the Baikal seismic zone located at the boundary between the mantle lense of the Siberian craton and the Amur plate.

Highlighted are seismic sutures with clusters of earthquakes that occurred in three seismic cycles. Large arrows - trajectories of the deformation wave before and after interaction with the mantle structure; solid arrows - directions of transverse migration of earthquakes; dotted arrows - longitudinal migration of earthquakes; blue line - contours of the anomalous mantle; the lithosphere depth at $75 \mathrm{~km}$ is shown according to [Zorin, Turutanov, 2005].

Сейсмические швы Байкальской зоны. Если деформационные волны задают временные характеристики сейсмичности, то глубинная структура литосферы играет решающую роль в пространственных особенностях распределения землетрясений. Для западного фланга Байкальской зоны главное значение имеет мантийная линза, которая изменяет направление перемещения волны деформаций (рис. 12). Ее положение и морфология определяют позицию и ориентировку двух сейсмических швов, в которых сосредоточены самые сильные землетрясения первого и третьего циклов. Отраженная мантийной линзой деформационная волна уходит на юго-восток и активизирует западную границу Амурской плиты. С этой границей генетически связан третий сейсмический шов Байкальской зоны. Эпицентры всех самых сильных землетрясений 
региона с магнитудой $\mathrm{M} \geq 6.5$, которые произошли за последние 150 лет, локализуются в описанных трех сейсмических швах. Они определяют, по всей видимости, локализацию не только самых сильных толчков, но и региональное распределение сейсмичности Байкальской зоны в целом. В границы сейсмических швов попадают, например, все участки высокой плотности эпицентров, полученные при прямой обработке параметров 30000 землетрясений магнитудой $2.5 \leq \mathrm{M} \geq 7.7$ за 1961-1999 гг. [Sherman, 2009]. Близкий рисунок районов максимального выделения энергии деформаций получен исходя из вариаций сейсмического момента, рассчитанных для землетрясений с магнитудой $\mathrm{M} \geq 6$ за последние 260 лет [Klyuchevskii, Dem'yanovich, 2009]. В этой работе показано также, что к этим «концентраторам напряжений» приурочены и палеосейсмодислокации последних 2000 лет. Три выделенных сейсмических шва определяют, по всей видимости, главные пространственные характеристики Байкальской сейсмической зоны на современном этапе в целом.

В разломно-блоковой структуре региона не существует региональных нарушений, вдоль которых бы протягивались выделенные сейсмические швы. Напротив, генезис множества разломов, прежде всего сдвигов и сбросо-сдвигов, явно обусловлен деформациями в пределах этих швов. Особенности геометрии Байкальской сейсмической зоны контролируются, прежде всего, структурой литосферной мантии. Именно она определяет расположение тех литосферных зон, вдоль которых энергия деформационных волн передается к поверхности. Сейсмические швы отмечают эти зоны на уровне коры, и постоянство их позиции предопределено глубинной структурой литосферы. На северовостоке и юго-западе Байкальской зоны сейсмические швы сближаются и накладываются. Интенсивность деформаций здесь, по всей видимости, достигает максимальных значений. Известные контуры аномальной мантии [Zorin, Turutanov, 2005], очевидно, совпадают с положением сейсмических швов в Байкальской зоне (рис. 12). Образование этой области разуплотнения в верхней мантии является, скорее всего, следствием тех деформаций, в которые вовлекается весь разрез литосферы на краю Сибирского кратона.

Ортогональный тип сейсмической миграции. Сочетание, порой одновременное, разных направлений регионального сжатия в Байкальской сейсмической зоне заслуживает отдельного внимания. Ключевым элементом является «ортогональная миграция», которая обозначает сочетание продольного и поперечного направлений миграции эпицентров землетрясений в пределах сейсмических швов. Во всех трех швах Байкальской зоны самые сильные землетрясения магнитудой $\mathrm{M} \geq 6.8$ мигрируют в поперечном направлении. Более слабые землетрясения, магнитуда которых отвечает диапазону $4.0 \leq \mathrm{M} \geq 6.0$, подчиняются продольной миграции. Повидимому, для образования сейсмогенных разрывов, ориентированных по касательной к границам лито- сферной структуры, требуется значительно меньше энергии. По этой же причине, скорее всего, среди разломов региона господствуют северо-восточные сдвиги [Parfeevets et al., 2002; Rundquist et al., 1999; Sherman, Levi, 1978]. Характерное для Байкальской рифтовой зоны сочетание сдвигов и сбросов также, по нашему мнению, наследует ортогональное распределение сжатия, которое возникает при взаимодействии деформационных волн с литосферной структурой.

В каждом из швов направления сейсмической миграции заметно различаются, что создает сложную общую картину в Байкальской сейсмической зоне (рис. 12). Одна из ее главных особенностей заключается в том, что продольная миграция землетрясений на флангах Байкальской зоны происходит во встречном направлении. В обоих юго-западных сейсмических швах она ориентирована с запада на восток. В северной же части Западно-Амурского шва продольная миграция должна быть направлена против часовой стрелки, а значит, с востока на запад. Это следствие общей модели вполне объясняет феномен встречной миграции землетрясений в юго-западной и северо-восточной частях Байкальской зоны [Sherman, Gorbunova, 2010].

Разная ориентировка сжатия в сейсмических швах создает сложный рисунок поля напряжений, в котором разные типы деформаций по-разному сочетаются на разных участках Байкальской зоны. Западно-Амурский и Байкало-Монгольский сейсмические швы определяют характер поля напряжений на ее северовосточном фланге. Судя по миграции сейсмичности (рис. 12), для обоих швов векторы главного поперечного сжатия здесь ориентированы в юго-восточном направлении. В результате растяжение на региональном уровне имеет выраженное северо-западное направление [Parfeevets et al., 2002]. На юго-западном фланге Байкальской зоны поле напряжений определяется взаимодействием уже Байкало-Монгольского и Байкало-Алтайского швов, у которых в одном северовосточном направлении ориентированы векторы продольного сжатия. Большую роль на юго-западном фланге зоны играет сдвиговый режим, а рифтогенные впадины развиваются при сочетании сдвига с растяжением [Lunina, Gladkov, 2004; Parfeevets et al., 2002]. С учетом простого тектонофизического механизма появления ортогональной миграции землетрясений, она может иметь широкое распространение в сейсмических областях, генетически связанных с деформационными волнами.

К тектонической природе рифтогенеза. Процессы растяжения в Байкальской зоне начались еще 50-40 млн лет назад [Logachev, 2003], вероятно, под воздействием коллизии Индо-Австралийской плиты с Евразией [Zonenshain, Savostin, 1979; Molnar, Tapponnier, 1975]. В этот период Амурская плита начала свой дрейф в юго-восточном направлении, а ведущую роль в рифтогенезе, скорее всего, играли перемещения и ротация тектонических блоков. Если не использовать 
плюмовую гипотезу, то миграция кайнозойского щелочно-базальтового вулканизма с юга на север в Монголии в интервале 50-7 млн лет, видимо, отражает вращение Амурской плиты по часовой стрелке до конца миоцена.

Рифтогенез начался в районе Южного Байкала, там, где наиболее сближены Амурская плита и Сибирский кратон (рис. 12), и постепенно распространялся на северо-восток и юго-запад [Logachev, 2003]. С учетом глубинной структуры литосферы, такой сценарий выглядит наиболее оптимальным в геодинамическом отношении. Зарождение Байкальской рифтовой зоны произошло над краем основания Сибирского кратона, и зона растяжения развивалась вдоль границы линзы подкратонной мантии. В этом отношении развитие кайнозойского рифтогенеза ничем не отличалось от его более ранних этапов в регионе (см. рис. $8, B$ ).

На границе с плиоценом произошла смена поля напряжений, усиление растяжения литосферы и ускорение тектонических движений [Logachev, 2003]. Началась и продолжается поныне стадия «быстрого рифтинга», с некомпенсируемым погружением Байкальской впадины. Участие деформационной волны в региональном растяжении разумно предполагать лишь для этой последней стадии рифтогенеза. Согласованность в положении сейсмических швов и рифтовых впадин предполагает (см. рис. 9, C), что рифтогенез и сейсмичность на современном этапе тектонической эволюции Байкальской зоны являются разными следствиями единого механизма, в основе которого лежит взаимодействие волны деформаций с литосферной структурой. С региональным сжатием связано образование сильных землетрясений Байкальской зоны. Компенсирующее растяжение в сейсмических швах, суммируясь за десятки тысяч циклов деформаций, приводит к образованию рифтогенных впадин. Наиболее интенсивно этот процесс проявлен там, где сейсмические швы сближаются и совмещаются в пространстве. Южно-Байкальская впадина в этом отношении уникальна, так как в этом районе суммируются напряжения всех трех сейсмических швов (рис. 12). Возможно, это та причина, которая определила и наивысшую степень раздробленности дна Южно-Байкальской впадины, и наиболее интенсивное прогибание здесь Байкальского рифта [Logachev, 2003].

Деформационные швы, как одна из основных структур Байкальской зоны, являются концентраторами напряжений, реализуемых в сейсмичности. При таком подходе предлагаемая модель деформационной волны логически объясняет, например, формирование своеобразной структуры Байкальской котловины. Как известно, дно озера состоит из трех хорошо морфологически выраженных впадин (рис. 13, A). Согласованность в положении позволяет сравнить ориентировку каждой из впадин озера с одним из деформационных (сейсмических) швов. Алтае-Байкальскому шву отвечает самая глубокая Средняя впадина, и связь их под- черкнута характерным северо-восточным простиранием поднятия о. Ольхон. Разумно предполагать, что деформационная волна, теряя при каждом взаимодействии с мантийной структурой часть энергии, постепенно разрушается. С этим эффектом, по нашему мнению, связано увеличение поперечника деформационных швов. Ширина первого - Алтае-Байкальского - минимальна, порядка 160 км, для Монголо-Байкальского она возрастает до 220 км и становится в два раза больше - 440 км - для Западно-Амурского шва. С другой стороны, потеря энергии должна приводить к уменьшению степени воздействия деформационной волны на динамику литосферы (рис. 13, B). Сопоставляя ширину сейсмических швов и глубину впадин, обнаруживаем четкую корреляцию между ними. Это предполагает, что сама морфоструктура рифтогенной котловины озера обусловлена расположением деформационных швов. Их влияние на развитие рифтогенеза в Байкальской зоне деструкции может быть очень глубоким и заслуживает дальнейшего специального изучения.

\section{7. ЗАКЛЮЧЕНИЕ}

Результаты исследования развивают тектонический подход к пониманию внутриплитной Байкальской сейсмической зоны, генезис которой объясняется столкновением планетарных плит в Гималайской зоне [Zonenshain, Savostin, 1979; Molnar, Tapponnier, 1975]. Недостатки и ограничения этого направления исследований связаны, по нашему мнению, с господством разломно-блокового представления о передаче энергии деформаций из области коллизии в глубину континента. Тектонофизический механизм взаимодействия блоков действует в масштабах миллионов лет. Деформационные волны являются другим «быстрым» механизмом разгрузки напряжений, которые постоянно накапливаются при столкновении плит. Привлечение гипотезы глубинных деформационных волн позволяет, по нашему мнению, приблизиться к пониманию особенностей сейсмотектоники и сейсмодинамики Байкальской рифтовой зоны.

Основную роль в сейсмичности региона играет деформационная волна, которая приходит в Байкальскую сейсмическую зону через 50 лет, последние три раза: в конце XIX - начале XX в., затем в середине XX в. и последний раз на границе XX и XXI вв. Существование цикличности с периодом в 50 лет для самых сильных землетрясений Земли предполагалось неоднократно. Действительно, все катастрофические землетрясения прошедшего столетия с магнитудой $\mathrm{M} \geq 8.8$ отвечают выделенным для Байкальской зоны временным периодам. В первом цикле произошло землетрясение (1906 г., M=8.8) на границе Колумбии и Эквадора. Во втором цикле произошли самые катастрофические события: на Камчатке (1952 г., М=9.0), в Чили (1960 г., 


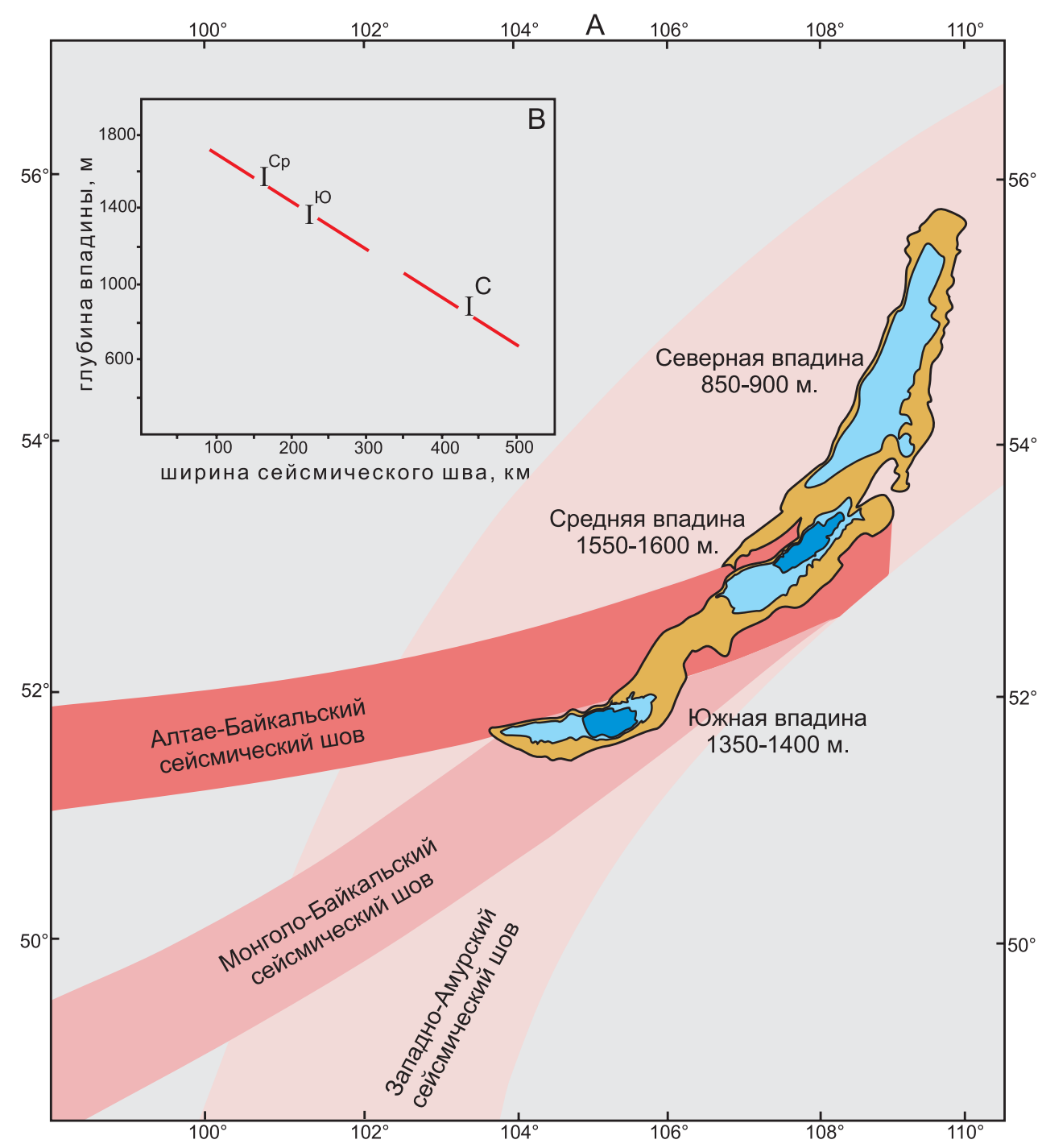

Рис. 13. Соотношение характеристик сейсмических швов зоны и морфоструктуры Байкальской котловины.

$A$ - взаиморасположение сейсмических швов зоны и впадин оз. Байкал; $B$ - корреляция глубины Байкальских впадин (Ср - Средняя, С Северная и Ю - Южная впадины) и ширины трех сейсмических швов.

Fig. 13. Correlation between characteristics of seismic sutures of the zone and the morphological structure of the Baikal basin.

$A$ - positions of the seismic sutures and Lake Baikal basins; $B$ - correlation between depths of the Baikal basins (Cp - Middle, C - Northern, and Ю - Southern basins) and widths of the three seismic sutures.

M=9.5) и на Аляске (1964 г., M=9.2). Затем перерыв в 50 лет и начало третьего цикла катастрофических землетрясений: у берегов Суматры (2004 г., М=9.1), в Чили (2010 г., М=8.8) и в Японии (2011 г., M=9.0). Вероятно, сейсмичность Байкальской зоны вызвана деформационной волной, которая определяет или наследует ритмику планетарной сейсмической активности в целом.

Наряду с сейсмодинамикой Северного Китая [Stepashko, 2011b] и Дальнего Востока России [Stepashko, 2010, 2011a], Байкальская сейсмическая зона является еще одним подтверждением прямого участия верхней мантии в наиболее масштабных деформационных процессах, вызывающих самые сильные землетрясения.
Образование зон внутриплитной сейсмичности происходит там, где мантийные структуры заставляют деформационные волны расходовать свою энергию. Особенности региональной сейсмичности оказываются своеобразным слепком глубинной структуры литосферы. Развитие кайнозойского рифтогенеза у края Сибирского кратона также, несомненно, наследует особенности мантийной структуры. Это соответствие подчеркивает плодотворность изучения региональных структур верхней мантии для прогресса ключевых направлений современной геологии. Важнейшая и практически не изученная до сих пор информация о мантийной структуре заключена, как было показано, в характере зональности мантийных перидотитов. Но в 
целом при региональном исследовании необходимо учитывать как геофизический, так и петрогеохимический образы мантии, согласованность которых должна служить критерием достоверности моделей глубинной структуры литосферы.

Результаты работы подтверждают перспективность концепции деформационных волн для изучения региональной сейсмичности [Sherman, 2013]. Главное препятствие на этом пути - заведомо иерархический и триггерный характер волновых деформаций в сейсмической зоне [Sherman, 2013]. Главная волна способна порождать каскад все более слабых деформационных волн, каждая из которых обладает собственными миграционными и ритмическими особенностями. Наложение землетрясений, вызванных разными деформационными волнами, создает запутанную картину совокупной сейсмичности, расшифровка которой является сложной задачей. Ее решение должно начинаться с отдельного анализа самых сильных землетрясений региона, в пространственно-временном распределении которых отражены особенности только главной волны деформаций. Пример Байкальской сейсмической зоны подчеркивает необходимость одновременного изучения циклических и миграционных характеристик региональной сейсмичности, поскольку закономерный характер миграции обнаруживается лишь для землетрясений конкретного цикла.

Ключевой особенностью Байкальской сейсмической зоны, имеющей очевидное прогнозное значение, является «шовная» структура пространственно-временного распределения сильных землетрясений. В настоящее время уже закончился или заканчивается цикл, сильные землетрясения которого были сосредоточены в Алтае-Байкальском шве. В следующем цикле сейсмическая активность должна перейти в МонголоБайкальский шов, где будет происходить накопление и разгрузка региональных деформаций в ближайшие 50 лет. Модель взаимодействия волн деформаций со структурой литосферной мантии юго-западного обрамления Сибирского кратона создает основу для контроля напряжений в деформационных швах, что имеет принципиальное значение для прогноза сильных землетрясений в Байкальской сейсмической зоне.

\section{8. ЛИТЕРАТУРА / REFERENCES}

Ashchepkov I.V., 1991. Deep Xenoliths of the Baikal Rift. Nauka, Novosibirsk, 160 p. (in Russian) [Ащепков И.В. Глубинные ксенолиты Байкальского рифта. Новосибирск: Наука, 1991. 160 с.].

Ashchepkov I.V., Pokhilenko N.P., Vladykin N.V., Logvinova A.M., Afanasiev V.P., Pokhilenko L.N., Kuligin S.S., Malygina E.V., Alymova N.A., Kostrovitsky S.I., Rotman A.Y., Mityukhin S.I., Karpenko M.A., Stegnitsky Yu.B., Khmelnikova O.S., 2010. Structure and evolution of the lithospheric mantle beneath Siberian craton, thermobarometric study. Tectonophysics 485 (1-4), 17-41. http://dx.doi.org/10.1016/j.tecto.2009.11.013.

Barruol G., Deschamps A., Deverchere J., Mordvinova V.V., Ulziibat M., Perrot J., Artem'ev A.A., Dugarmaa T., Bokelmann G.H.R., 2008. Upper mantle flow beneath and around the Hangay dome, Central Mongolia. Earth and Planetary Science Letters 274 (1-2), 221-233. http://dx.doi.org/10.1016/j.epsl.2008.07.027.

Bykov V.G., 2005. Strain waves in the Earth: theory, field data, and models. Russian Geology and Geophysics 46 (11), 11761190.

Chen C.-W., Rondenay S., Evans R.L., Snyder D.B., 2009. Geophysical detection of relict metasomatism from an archean ( 3.5 Ga) subduction zone. Science 326 (5956), 1089-1091. http://dx.doi.org/10.1126/science.1178477.

Didenko A.N., Mossakovsky A.A., Pechersky D.M., Ruzhentsev S.V., Samygin S.G., Kheraskova T.N., 1994. Geodynamics of the Central-Asian paleozoic oceans. Geologiya i Geofizika (Russian Geology and Geophysics) 35 (7-8), 59-75 (in Russian) [Диденко А.Н., Моссаковский А.А., Печерский Д.М., Руженцев С.В., Самыгин С.Г., Хераскова Т.Н. Геодинамика палеозойских океанов Центральной Азии // Геология и геофизика. 1994. Т. 35. № 7-8. С. 59-75].

Egorkin A.V., 2004. Mantle structure of the Siberian platform. Izvestia, Physics of the Solid Earth 40 (5), 385-394.

Ferrini V., Sassano G., 1999. Nature, origin and age of diamonds: a state-of-the-art report. Periodico Di Mineralogia 68 (2), 109-126.

Gaul O.F., Griffin W.L., O’Reilly S.Y., Pearson N.J., 2000. Mapping olivine composition in the lithospheric mantle. Earth and Planetary Science Letters 182 (3-4), 223-235. http://dx.doi.org/10.1016/S0012-821X(00)00243-0.

Glorie S., De Grave J., Buslov M.M., Zhimulev F.I., Izmer A., Vandorne W., Ryabinin A., Van der haute P., Vanhaecke F., Elburg M.A., 2011. Formation and Palaeozoic evolutin of the Gorny-Altai-Altai-Mongolia suture zone (South Siberia): Zircon U/Pb constraints on the igneous record. Gondwana Research 20 (2-3), 465-484. http://dx.doi.org/10.1016/j.gr. 2011.03.003.

Glukhovsky M.Z., 1990. Geological Evolution of Basements of Ancient Platforms (Nuclear Conception). Nauka, Moscow, 215 p. (in Russian) [Глуховский М.3. Геологическая эволюция фундаментов древних платформ (Нуклеарная концепция). М.: Наука, 1990. 215 с.].

Gossler J., Kind R., 1996. Seismic evidence for very deep roots of continents. Earth and Planetary Science Letters 138 (1-4), 1-13. http://dx.doi.org/10.1016/0012-821X(95)00215-X. 
Griffin W.L., Doyle B.J., Ryan C.G., Pearson N.J., O’Reilly S.Y., Davies R.M., Kivi K., van Achterberg E., Natapov L.M., 1999. Layered mantle lithosphere in the Lac de Gras, Slave Craton: composition, structure and origin. Journal of Petrology 40 (5), 705-727. http://dx.doi.org/10.1093/petroj/40.5.705.

Griffin W.L., O’Reilly S.Y., Afonso J.C., Begg G.C., 2009. The composition and evolution of lithospheric mantle: a reevaluation and its tectonic implications. Journal of Petrology 50 (7), 1185-1204. http://dx.doi.org/10.1093/petrology/ egn033.

Gundmundsson O., Sambridge M., 1998. A regionalized upper mantle (RUM) seismic model. Journal of Geophysical Research: Solid Earth 103 (B4), 7121-7136. http://dx.doi.org/10.1029/97JB02488.

Herzberg C., 2004. Geodynamic information in peridotite petrology. Journal of Petrology 45 (12), 2507-2530. http://dx.doi. org/10.1093/petrology/egh039.

Ionov D.A., Hofmann A.W., 2007. Depth of formation of subcontinental off-craton peridotites. Earth and Planetary Science Letters 261 (3-47), 620-634. http://dx.doi.org/10.1016/j.epsl.2007.07.036.

Ishikawa A., Maruyama S., Komiya T., 2004. Layered lithospheric mantle beneath the Ontong Java Plateau: Implications from xenoliths in Alnoite, Malaita, Solomon Islands. Journal of Petrology 45 (10), 2011-2044. http://dx.doi.org/10.1093/ petrology/egh046.

Ivanova T.P., Trifonov V.G., 2005. Neotectonics and mantle earthquakes in the Pamir-Hindu Kush Region. Geotectonics 39 (1), 56-68.

Jordan T.H., 1978. Composition and development of the continental tectosphere. Nature 274 (5671), 544-548. http://dx. doi.org/10.1038/274544a0.

Kiselev A.I., Medvedev M.E., Golovko G.A., 1979. Volcanism of the Baikal Rift Zone and Origination Problems of Deep Magma. Nauka, Novosibirsk, 197 p. (in Russian) [Киселев А.И., Медведев М.Е., Головко Г.А. Вулканизм Байкальской рифтовой зоны и проблемы глубинного магмообразования. Новосибирск: Наука, 1979. 197 с.].

Klyuchevskii A.V., Dem'yanovich V.M., 2009. Baikal rift zone: an area of higher energy of seismotectonic deformations in the lithosphere. Doklady Earth Sciences 429 (1), 1314-1317. http://dx.doi.org/10.1134/S1028334X09080169.

Kondorskaya N.V., Shebalin N.V., 1977. The New Catalog of Strong Earthquakes in the Territory of USSR from Ancient Times to 1975. Nauka, Moscow, 536 p. (in Russian) [Кондорская Н.В., Шебалин Н.В. Новый каталог сильных землетрясений на территории СССР с древнейших времен до 1975 г. М.: Наука, 1977. 536 с.].

Kontorovich A.E., Belyaev S.Yu., Kontorovich A.A., Starosel'tsev V.S., Mandel'baum M.M., Migurskii A.V., Moiseev S.A., Safronov A.F., Sitnikov V.S., Fliptsov Yu.A., Khomenko A.V., Eremin Yu.G., Bykova O.V., 2009. Tectonic map of the Vendian - Lower Paleozoic structural stage of the Lena - Tunguska petroleum province, Siberian Platform. Russian Geology and Geophysics 50 (8), 657-667. http://dx.doi.org/10.1016/j.rgg.2008.10.005.

Koulakov I., Bushenkova N., 2010. Upper mantle structure beneath the Siberian craton and surrounding areas based on regional tomographic inversion of P and PP travel times. Tectonophysics 486 (1-4), 81-100. http://dx.doi.org/10.1016/ j.tecto.2010.02.011.

Kuskov O.L., Kronrod V.A., Annersten H., 2006. Inferring upper-mantle temperatures from seismic and geochemical constraints: Implications for Kaapvaal craton. Earth and Planetary Science Letters 244 (1-2), 133-154. http://dx.doi.org/ 10.1016/j.epsl.2006.02.016.

Lapin B.N., 1997. Atlas of Structures of Alpine-Type Hyperbasites from Siberia and Far East. Publishing House of SB RAS, OIGGM, Novosibirsk, 331 p. (in Russian) [Лапин Б.Н. Атлас структур пород альпинотипных гипербазитов Сибири и Дальнего Востока. Новосибирск: Издательство СО РАН, НИЦ ОИГГМ, 1997. 331 с.].

Lee C.-T. A., Luffi P., Chin E.J., 2011. Building and destroying continental mantle. Annual Review of Earth and Planetary Sciences 39, 59-90. http://dx.doi.org/10.1146/annurev-earth-040610-133505.

Lesnov F.P., 1986. Petrochemistry of Polygenic Basite-Hyperbasite Plutons from Folded Regions. Nauka, Novosibirsk, 136 p. (in Russian) [Леснов Ф.П. Петрохимия полигенных базит-гипербазитовых плутонов складчатых областей. Новосибирск: Наука, 1986. 136 с.].

Logachev N.A., 2003. History and Geodynamics of the Baikal Rift. Russian Geology and Geophysics 5, 373-387.

Luguet A., Jaques A.L., Pearson D.G., Smith C.B., Bulanova G.P., Roffey S., Rayner M., Lorand J.P., 2009. An integrated petrological, geochemical and Re-Os isotope study of peridotite xenoliths from the Argyle lamproite, Western Australia and implications for cratonic diamond occurrences. Lithos 112 (2), 1096-1108. http://dx.doi.org/10.1016/j.lithos.2009. 05.022.

Lunina O.V., Gladkov A.S., 2004. Fault pattern and stress field in the western Tunka rift (southwestern flank of the Baikal rift system). Russian Geology and Geophysics 45 (10), 1188-1199.

Malamud A.S., Nikolaevsky V.N., 1983. Periodicity of the Pamir - Hindu Kush earthquakes and tectonics waves in subducting lithospheric plates. Doklady AN 269 (5), 1075-1078 (in Russian) [Маламуд А.С., Николаевский В.Н. Периодичность Памиро-Гиндукушских землетрясений и тектонические волны в субдуктируемых литосферных плитах // Доклады АН. 1983. Т. 269. № 5. С. 1075-1078].

Malamud A.S., Nikolaevsky V.N., 1985. Cyclicity of seismotectonic events at the edges of the Indian lithospheric plate. Doklady AN 282 (6), 1333-1337 (in Russian) [Маламуд А.С., Николаевский В.Н. Цикличность сейсмотектонических со- 
бытий на краях Индийской литосферной плиты // Доклады АН СССР. 1985. Т. 282. № 6. С. 1333-1337].

McDonough W.F., Sun S.S., 1995. The composition of the Earth. Chemical Geology 120 (3-4), 223-253. http://dx.doi.org/ 10.1016/0009-2541(94)00140-4.

Menzies A.N., Shirey S.B., Carlson R.W., Gurney J.J., 1998. Re-Os isotope systematics of diamond bearing eclogites and peridotites from Newlands kimberlite. In: J.J. Gurney, J.L. Gurney, M.D. Pascoe, S.H. Richardson (Eds.), Extended Abstracts $7^{\text {th }}$ International Kimberlite Conference. Red Roof Design, Cape Town, p. 579-581.

Mironyuk E.P., Zagruzina I.A., 1983. Geoblocks of Siberia and stages of their formation. In: Tectonics of Siberia. The Structure of the Earth's Crust in the Eastern Region of the USSR in the Light of Modern Tectonic Concepts. Nauka, Novosibirsk, V. XI, p. 133-140 (in Russian) [Миронюк Е.П., Загрузина И.А. Геоблоки Сибири и этапы их формирования // Тектоника Сибири. Строение земной коры востока СССР в свете современных тектонических концепций. Новосибирск: Наука, 1983. Т. ХІ. С. 133-140].

Mitrofanov G.L., Taskin A.P., 1994. Structural relationships of the Siberian platform with the folded framing. Geotektonika (Geotectonics) 1, 3-15 (in Russian) [Митрофанов Г.Л., Таскин А.П. Структурные соотношения Сибирской платформы со складчатым окружением // Геотектоника. 1994. № 1. С. 3-15].

Molnar P., Tapponnier P., 1975. Cenozoic tectonic of Asia: Effects of continental collision. Science 189 (4201), 419-426. http://dx.doi.org/10.1126/science.189.4201.419.

National Earthquake Information Center - NEIC, 2013. Available from: http://earthquake.usgs.gov/regional/neic/ (last accessed 29.10.2013).

O’Reilly S.Y., Griffin W.L., 2006. Imaging global chemical and thermal heterogeneity in the subcontinental lithospheric mantle with garnets and xenoliths: Geophysical implications. Tectonophysics 416 (1-4), 289-309. http://dx.doi.org/10. 1016/j.tecto.2005.11.014.

Parfeevets A.V., San'kov V.A., Miroshnichenko A.I., Lukhnev A.V., 2002. The evolution of the state of stresses of the Earth's crust of the Mongol-Baikal mobile belt // Tikhookeanskaya Geologiya (Russian Journal of Pacific Geology) 21 (1), 14 28 (in Russian) [Парфеевец А.В., Саньков В.А., Мирошниченко А.И., Лухнев А.В. Эволюция напряженного состояния земной коры Монголо-Байкальского подвижного пояса // Тихоокеанская геология. 2002. Т. 21. № 1. С. 14-28].

Patel S.C., Ravi S., Anilkumar Y., Pati J.K., 2010. Major element composition of concentrate garnets in Proterozoic kimberlites from the Eastern Dharwar Craton, India: Implications on sub-continental lithospheric mantle. Journal of Asian Earth Sciences 39 (6), 578-588. http://dx.doi.org/10.1016/j.jseaes.2010.04.020.

Pavlenkova G.A., Pavlenkova N.I., 2006. Upper mantle structure of the Northern Eurasia from peaceful nuclear explosion data. Tectonophysics 416 (1-4), 33-52. http://dx.doi.org/10.1016/j.tecto.2005.11.010.

Pavlenkova N.I., 2011. Seismic structure of the upper mantle along the long-range PNE profiles - rheological implication. Tectonophysics 508 (1-4), 85-95. http://dx.doi.org/10.1016/j.tecto.2010.11.007.

Pearson D.G., 1999. The age of continental roots. Lithos 48 (1-4), 171-194. http://dx.doi.org/10.1016/S0024-4937(99) 00026-2.

Pearson D.G., Shirey S.B., Bulanova G.P., Carlson R.W., Milledge H.J., 1999. Re-Os isotope measurements of single sulfide inclusions in a Siberian diamond and its nitrogen aggregation systematics. Geochimica et Cosmochimica Acta 63 (5), 703-711. http://dx.doi.org/10.1016/S0016-7037(99)00042-3.

Pearson D.G., Wittig N., 2008. Formation of Archaean continental lithosphere and its diamonds: the root of the problem. Journal of the Geological Society 165 (5), 895-914. http://dx.doi.org/10.1144/0016-76492008-003.

Pechersky D.M., Didenko A.N., 1995. Paleo-Asian Ocean: Petromagnetic and Paleomagnetic Information about Its Lithosphere. Publishing House of OIFZ RAN, Moscow, 298 p. (in Russian) [Печерский Д.М., Диденко А.Н. Палеоазиатский океан: петромагнитная и палеомагнитная информация о его литосфере. М.: ОИФЗ РАН, 1995. 298 с.].

Peltonen P., Brugmann G., 2006. Origin of layered continental mantle (Karelian craton, Finland): Geochemical and Re-Os isotope constraints. Lithos 89 (3-4), 405-423. http://dx.doi.org/10.1016/j.lithos.2005.12.013.

Polet J., Anderson D.L., 1995. Depth extent of cratons as inferred from tomographic studies. Geology 23 (3), 205-208. http:// dx.doi.org/10.1130/0091-7613(1995)023<0205:DEOCAI>2.3.CO;2.

Rudnick R.L., Walker R.J., 2009. Interpreting ages from Re-Os isotopes in peridotites. Lithos 112 (2), 1083-1095. http://dx. doi.org/10.1016/j.lithos.2009.04.042.

Rundquist D.V., Sobolev P.O., Ryakhovskii V.M., 1999. Reflection of different fracture types in the seismicity of the Baikal Rift Zone. Doklady Earth Sciences 367 (5), 708-710.

Rytsk E.Yu., Shalaev V.S., Rizvanova N.G., Krymskii R.Sh., Makeev A.F., Rile G.V., 2002. The Olokit zone of the Baikal fold region: new isotope-geochronological and petrochemical data. Geotectonics 36 (1), 24-35.

San'kov V.A., Parfeevets A.V., Lukhnev A.V., Miroshnichenko A.I., Ashurkov S.V., 2011. Late Cenozoic geodynamics and mechanical coupling of crustal and upper mantle deformations in the Mongolia - Siberian Mobile Region. Geotectonics 45 (5), 378-393. http://dx.doi.org/10.1134/S0016852111050049.

Sand K.K., Waight T.E., Pearson D.G., Nielsen T.F.D., Makovicky E., Hutchison M.T., 2009. The lithospheric mantle below southern west Greenland: A geothermobarometric approach to diamond potential and mantle stratigraphy. Lithos 112 (2), 
A.A. Stepashko: The structure of the lithospheric mantle of the Siberain craton...

1155-1166. http://dx.doi.org/10.1016/j.lithos.2009.05.012.

Savage M.K., 1999. Seismic anisotropy and mantle deformation: what have we learned from shear wave splitting. Reviews of Geophysics 37 (1), 65-106. http://dx.doi.org/10.1029/98RG02075.

Schulze D.J., Canil D., Channer D.M.D., Kaminsky F.V., 2006. Layered mantle structure beneath the western Guyana Shield, Venezuela: Evidence from diamonds and xenocrysts in Guaniamo kimberlites. Geochemica et Cosmochimica Acta 70 (1), 192-205. http://dx.doi.org/10.1016/j.gca.2005.08.025.

Şengör A.M.C., Natal'in B.A., 1996. Paleotectonics of Asia: fragments of a synthesis. In: A.Yin, M. Harrison (Eds.), The Tectonic Evolution of Asia. Cambridge University Press, Cambridge, p. 486-640.

Sherman S.I., 2009. A tectonophysical model of a seismic zone: experience of development based on the example of the Baikal rift system. Izvestia, Physics of the Solid Earth 45 (11), 938-951. http://dx.doi.org/10.1134/S1069351309110020.

Sherman S.I., 2013. Deformation waves as a trigger mechanism of seismic activity in seismic zones of the continental lithosphere. Geodynamics \& Tectonophysics 4 (2), 83-117. http://dx.doi.org/10.5800/GT-2013-4-2-0093.

Sherman S.I., Gorbunova E.A., 2010. New data on the regularities of the earthquake manifestation in the Baikal seismic zone and their forecast. Doklady Earth Sciences 435 (2), 1659-1664. http://dx.doi.org/10.1134/S1028334X10120238.

Sherman S.I., Levi K.G., 1978. Transform faults of the Baikal rift zone and seismicity of its flanks. In: Tectonics and seismisity of the continental rift zones. Nauka, Moscow, p. 7-18 (in Russian) [Шерман С.И., Леви К.Г. Трансформные разломы Байкальской рифтовой зоны и сейсмичность ее флангов // Тектоника и сейсмичность континентальных рифтовых зон. М.: Наука, 1978. С. 7-18].

Sherman S.I., Zlogodukhova O.G., 2011. Seismic belts and zones of the Earth: formalization of notions, positions in the lithosphere, and structural control. Geodynamics \& Tectonophysics 2 (1), 1-34. http://dx.doi.org/10.5800/GT-2011-2-1-0031.

Silver P.G., Chan W.W., 1991. Shear wave splitting and subcontinental mantle deformation. Journal of Geophysical Research: Solid Earth 96 (B10), 16429-16454. http://dx.doi.org/10.1029/91JB00899.

Snyder D.B., 2002. Lithospheric growth at margins of cratons. Tectonophysics 355 (1-4), 7-22. http://dx.doi.org/10.1016/ S0040-1951(02)00131-2.

Stepashko A.A., 1998. The Chemical Structure of Ultrabasic Mantle. Dalnauka, Vladivostok, 128 p. (in Russian) [Cmenauко А.А. Химическая структура ультраосновной мантии. Владивосток: Дальнаука, 1998. 128 с.].

Stepashko A.A., 2001. The upper mantle structure and geodynamics of the Siberian plate. In: Tectonics, deep structure and geodynamics of the Eastern Asia: The 3rd conference in memory of Yu.A. Kosygin. Publishing House of ITIG FEB RUS, Khabarovsk, p. 53-62 (in Russian) [Cтепашко А.А. Структура верхней мантии и геодинамика Сибирской платформы // Тектоника, глубинное строение и геодинамика востока Азии: III Косыгинские чтения. Хабаровск: ИТиГ им. Ю.А. Косыгина ДВО РАН, 2001. С. 53-62].

Stepashko A.A., 2010. Deep roots of seismotectonics in the Far East: The Sakhalin zone. Russian Journal of Pacific Geology 4 (3), 228-241. http://dx.doi.org/10.1134/S181971401003005X.

Stepashko A.A., 2011a. Deep roots of seismotectonics of the Far East: The Amur River and Primorye zones. Russian Journal of Pacific Geology 5 (1), 1-12. http://dx.doi.org/10.1134/S1819714011010076.

Stepashko A.A., 2011b. Seismodynamics and deep internal origin of the North China zone of strong earthquakes. Geodynamics \& Tectonophysics 2 (4), 341-355. http://dx.doi.org/10.5800/GT-2011-2-4-0049.

Stone R., 2008. An unpredictably violent fault. Science 320 (5883), 1578-1580. http://dx.doi.org/10.1126/science.320. 5883.1578.

Surkov V.S., Korobeinikov V.P., Krylov S.V., Grishin M.P., Kraevsky B.G., Larichev A.I., 1996. Geodynamic and depositional conditions of the Riphean petroleum complex formation at the western margin of the Siberian Paleocontinent. Geologiya i Geofizika (Russian Geology and Geophysics) 37 (8), 154-166 (in Russian) [Сурков В.С., Коробейников В.П., Крылов C.В., Гришин М.П., Краевский Б.Г., Ларичев А.И. Геодинамические и седиментационные условия формирования рифейских нефтегазоносных комплексов на западной окраине Сибирского палеоконтинента // Геология и геофизика. 1996. Т. 37. № 8. С. 154-166].

Ulomov V.I., 1993. Waves of seismogeodynamic activation and long-term prediction of earthquakes. Fizika Zemli (Physics of the Solid Earth) (4), 43-53 (in Russian) [Уломов В.И. Волны сейсмогеодинамической активизации и долгосрочный прогноз землетрясений // Физика Земли. 1993. № 4. С. 43-53].

Velinsky V.V., Vartanova N.S., 1980. Chemical patterns of the Tuva ultrabasic rocks. In: Petrology of ultrabasic and basic rocks from Siberia and the Far East of Russia and Mongolia. Nauka, Novosibirsk, p. 14-27 (in Russian) [Велинский В.В., Вартанова Н.С. Закономерности в химизме гипербазитов Тувы // Петрология гипербазитов и базитов Сибири, Дальнего Востока и Монголии. Новосибирск: Наука, 1980. С. 14-27].

Vernikovsky V.A., Vernikovskaya A.E., Nozhkin A.D., Ponomarchuk V.A., 1994. The Riphean ophiolites of the Isakovka belt (Yenisei Ridge). Geologiya i Geofizika (Russian Geology and Geophysics) 35 (7-8), 169-181 (in Russian) [Верниковский В.А., Верниковская А.Е., Ножкин А.Д., Пономарчук В.А. Рифейские офиолиты Исаковского пояса (Енисейский кряж) // Геология и геофизика. 1994. Т. 35. № 7-8. С. 169-181].

Vikulin A.V., Bykov V.G., Luneva M.N., 2000. Nonlinear deformation waves in a rotational model of a seismic process. Computational technologies 5 (1), 31-39. 
Vinnik L.P., Makeyeva L.I., Milev A., Usenko A.Yu., 1992. Global pattern of azimuthal anisotropy and deformations in the continental mantle. Geophysical Journal International 111 (3), 433-447. http://dx.doi.org/10.1111/j.1365-246X.1992. tb02102.x.

Vladimirov B.M., Volyanyuk N.Ya., Ponomarenko A.I., 1976. Deep Xenoliths from Kimberlites, Basalts and Kimberlite-like Rocks. Nauka, Moscow, 284 p. (in Russian) [Владимиров Б.М., Волянюк Н.Я., Пономаренко А.И. Глубинные включения из кимберлитов, базальтов и кимберлитоподобных пород. М.: Наука, 1976. 284 с.].

Wittig N., Pearson D.G., Webb M., Ottley C.J., Irvine G.J., Kopylova M., Jensen S.M., Nowell G.M., 2008. Origin of cratonic lithospheric mantle roots: A geochemical study of peridotites from the North Atlantic Craton, West Greenland. Earth and Planetary Science Letters 274 (1-2), 24-33. http://dx.doi.org/10.1016/j.epsl.2008.06.034.

Wittlinger G., Farra V., 2007. Converted waves reveal a thick and layered tectosphere beneath the Kalahari super-craton. Earth and Planetary Science Letters 254 (3-4), 404-415. http://dx.doi.org/10.1016/j.epsl.2006.11.048.

Xiao W., Huang B., Han C., Sun S., Li J., 2010. A review of the western part of the Altaids: A key to understanding the architecture of accretionary orogens. Gondwana Research 18 (2-3), 253-273. http://dx.doi.org/10.1016/j.gr.2010.01.007.

Xu X., Griffin W.L., O’Reilly S.Y., Pearson N.J., Geng H., Zheng J., 2008. Re-Os isotopes of sulfides in mantle xenoliths from eastern China: Progressive modification of lithospheric mantle. Lithos 102 (1-2), 43-64. http://dx.doi.org/10.1016/ j.lithos.2007.06.010.

Yarmolyuk V.V., Kovalenko V.I., Kotov A.B., Sal'nikova E.V., 1997. The Angara-Vitim Batholith: On the problem of batholith geodynamics in the Central Asia Foldbelt. Geotectonics 31 (5), 359-373.

Yuan H., Romanowicz B., 2010. Lithospheric layering in the North American craton. Nature 466 (7310), 1063-1068. http:// dx.doi.org/10.1038/nature09332.

Zoback M.D., 2010. Earthquakes: Climate and intraplate shocks. Nature 466 (7306), 568-569. http://dx.doi.org/10.1038/ 466568a.

Zonenshain L.P., Savostin V.G., 1979. Introduction to Geodynamics. Nedra, Moscow, 311 p. (in Russian) [Зоненшайн Л.П., Савостин Л.А. Введение в геодинамику. М.: Недра, 1979. 311 с.].

Zorin Yu. A. Turutanov E.Kh., 2005. Plumes and geodynamics of the Baikal rift zone. Russian Geology and Geophysics 46 (7), 669-682.

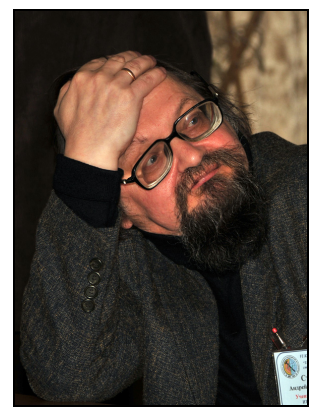

Степашко Андрей Анатольевич, канд. геол.-мин. наук., в.н.с.

Институт тектоники и геофизики им. Ю.А. Косыгина ДВО РАН

680000, Хабаровск, ул. Ким Ю Чена, 65, Россия

$\checkmark$ e-mail: stepashko@itig.as.khb.ru

Stepashko, Andrey A., Candidate of Geology and Mineralogy, Lead Researcher

Kosygin Institute of Tectonics and Geophysics, Far East Branch of RAS

65 Kim Yu Chen street, Khabarovsk 680000, Russia

$\triangle$ e-mail: stepashko@itig.as.khb.ru 